Article

\title{
Insight into Heterogeneous Calcite Cementation of Turbidite Channel-Fills from UAV Photogrammetry
}

\author{
Mattia Marini $\left.{ }^{1, *} \mathbb{(}\right)$, Giovanna Della Porta ${ }^{1}\left(\mathbb{D}\right.$, Fabrizio Felletti $^{1}\left(\mathbb{D}\right.$, Benedetta Marcella Grasso ${ }^{1}$, \\ Marica Franzini ${ }^{2}$ and Vittorio Casella ${ }^{2}$ iD \\ 1 Department of Earth Science 'Ardito Desio', University of Milan, 20133 Milan, Italy; \\ giovanna.dellaporta@unimi.it (G.D.P.); fabrizio.felletti@unimi.it (F.F.); \\ benedettamarcella.grasso@studenti.unimi.it (B.M.G.) \\ 2 Department of Civil Engineering and Architecture, University of Pavia, 27100 Pavia, Italy; \\ marica.franzini@unipv.it (M.F.); vittorio.casella@unimi.it (V.C.) \\ * Correspondence: mattia.marini@unimi.it
}

Received: 2 April 2019; Accepted: 13 May 2019; Published: 23 May 2019

\begin{abstract}
Diagenesis is a key controlling factor on sandstone porosity and permeability. Understanding type, paragenetic sequence and spatial patterns of cements is thus important for assessing sandstone hydrocarbon reservoir properties. In this study Unmanned Aerial Vehicle (UAV) photogrammetry is used to evaluate the shape and spatial distribution of calcite concretions developed within the sand-prone fill of a turbidite channel. The studied channel-fill is entrenched into hemipelagic marlstones and include a lower conglomeratic sandstone loaded with marlstone rip-ups and an upper fill featuring a range of turbidite bed types, which, up-section and off the channel axis, are progressively finer grained and less amalgamated. Concretion shape analysis highlighted a continuum of equant to oblate shapes with flat-lying major axes and a cumulative volume fraction of ca. $22 \%$. Equant to sub-equant concretions are ubiquitous and occur at different heights within beds, often developing around marlstone rip-ups. Conversely, elongated concretions are either strata-bound concretions or completely cemented beds which become volumetrically dominant up section and off the channel axis. The interparticle pore-space of concretions represents on average ca. $22 \%$ and is tightly filled by poikilotopic and blocky calcite cement precipitated near to maximum burial depth, whereas host sandstones lack calcite cements and show smectite clay cement and an average preserved porosity of ca. $15 \%$. The oxygen and carbon isotopes of calcite cements point to the marlstone as the main source of carbonate ions, suggesting concretions developed during burial by either diffusion from rip-ups and mud caps or recrystallization of, matrix micrite. Results suggest that the process by which the carbonate-rich component was eroded from the substrate and trapped within the channel-fill is a key control on spatial distribution of calcite concretions, likely to reflect on spatial variability of reservoir properties.
\end{abstract}

Keywords: turbidite channel; sandstone channel-fill; diagenesis; calcite concretion; unmanned aerial vehicle photogrammetry; hydrocarbon reservoir properties

\section{Introduction}

A striking feature of most calcite-cemented sandstones is their uneven diagenesis, resulting in tightly cemented concretions embedded in weakly to un- cemented host sands [1]. Because calcite cements fill-in interparticle pore spaces, concretions are typically non-reservoir and fluid tight [2-7], which makes understanding their spatial distribution and genesis key to develop predictive models [8].

Calcite concretions in sandstones have been extensively studied in a range of depositional [1,9-17] and diagenetic environments $[18,19]$, highlighting several interplaying controls including small-scale 
permeability variations $[1,10,13]$, presence of carbonate-rich clasts (e.g., shell fragments, lithics and intraformational rip-up clasts) acting as a source and/or nuclei for calcite cement overgrowth $[1,2,20,21]$ and internal architecture of depositional systems [7,17,21,22].

Calcite cement in sandstones has been reported to be selective to bioclast-rich layers of some shallow-marine examples [20,23], forming spheroidal concretions or completely cementing beds through a mechanism of carbonate diffusion. However, there are examples where calcite cement is not associated with carbonate skeletal or lithic fragments [1,11], implying carbonate advection from circulating water and selective precipitation within preferential flow paths.

In deep-water sandstones, carbonate concretions have been documented in both channelized and non-channelized turbidites, reporting contrasting shapes and distribution patterns and volume fractions of up to $30 \%$. In channelized turbidites calcite can massively precipitate aureole-like at the contact with embedding shales and marlstones [2,14], and/or form spheroidal concretions around carbonate-rich clasts [1,2], either intra- (e.g., marlstone rip-ups entrained locally by substrate erosion) or extra-formational (e.g., carbonate skeletal or lithic fragments). Conversely, in non-channelized turbidites (i.e., basin plain lobes and sheets) calcite cementation can completely cement beds or form strata-bound concretions, typically more elongated than observed in channelized turbidites [1]. On the other hand, neither textural (grain size, grading; [1,14]) nor grain composition controls [24] on calcite cementation have been demonstrated to date.

It is intriguing researching into whether this lack of correlation between concretion distribution and sandstone texture, facies and framework grain petrography is factual, or it rather reflects the impracticality of quantifying differential cementation at outcrop. In fact, only a few studies attempted to assess quantitatively the shape and likely spatial distribution of a statistically significant number of concretions in tandem with sedimentary facies distribution $[11,13,25]$.

Recent advances in remote sensing, photogrammetry and unmanned aerial vehicle (UAV) technologies make today possible the acquisition of detailed digital outcrop models, which can be used by geologists to extract scalars associated with geological features such as, for example, bedding and fracture orientation and lithology and sedimentary facies proportions [26-32].

Using a high-resolution digital outcrop model from UAV photogrammetry, the present contribution aims at assessing the shape, volume fraction and spatial distribution of calcite-cemented concretions within the channelized turbidite sandstones of the Late Oligocene Cappella della Valle Mb. (Gremiasco Formation, Tertiary Piedmont Basin of NW Italy), as well as linking these parameters to facies architecture. Complemented with petrographic and carbon and oxygen stable isotope providing constraints onto cement types and source of $\mathrm{CaCO}_{3}$, this contribution offers insights into mode and controls of heterogeneous calcite cementation, useful for predicting the poro-permeability complexity of analogue hydrocarbon reservoirs.

\section{Geological Setting}

The studied turbidite sandstones crop out in the eastern part of the Tertiary Piedmont Basin (TPB) of NW Italy (Figure 1), an episutural basin formed during the late Cretaceous - late Eocene collision of the European plate and Adria micro-plate [33-35]. Prolonged clastic deposition in the TPB resulted in a up to $3000 \mathrm{~m}$-thick late Eocene to early Miocene sedimentary pile (Figure 1) including several turbidite units (Monastero, Gremiasco and Castagnola Fms. [36-39]). 


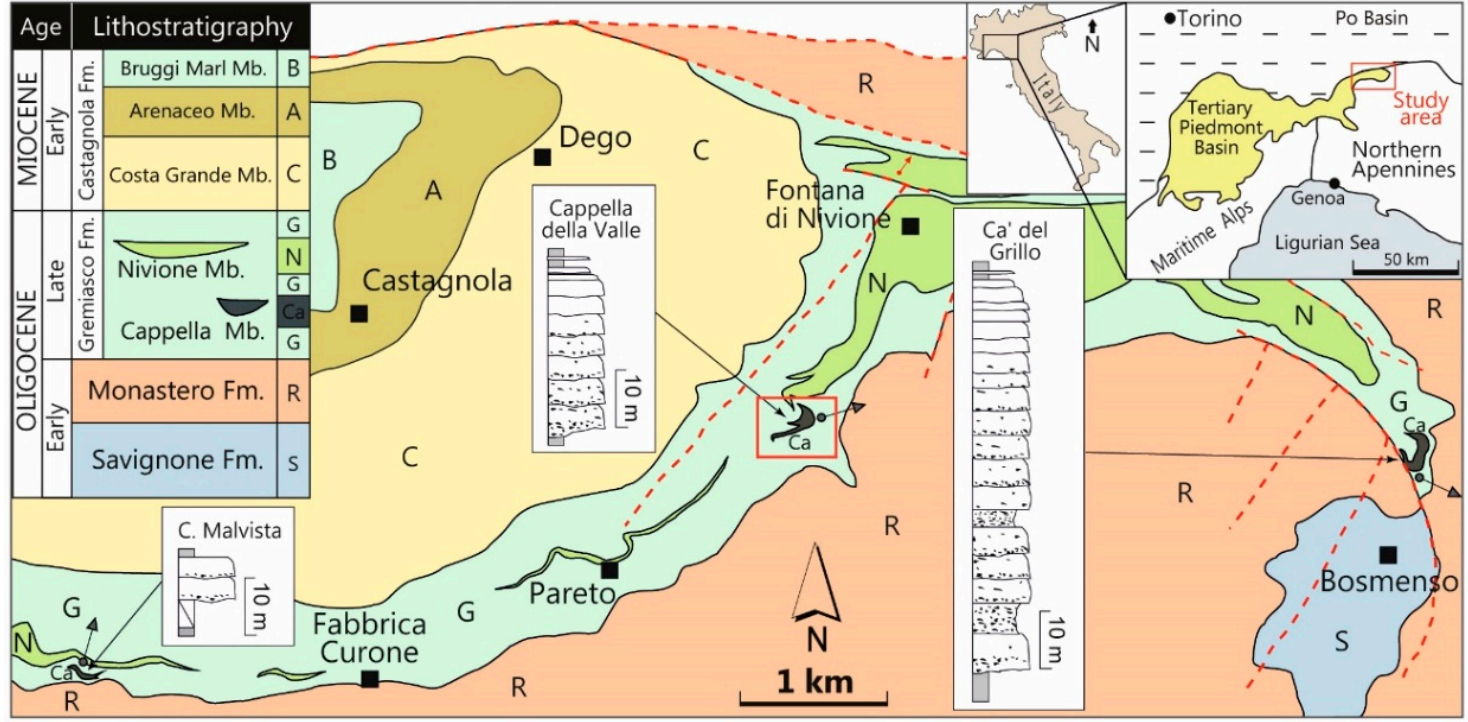

Figure 1. Simplified geological map (modified, after Cavanna et al. [40]) of the easternmost part of the Tertiary Piedmont Basin sedimentary (lithostratigraphy after Marroni et al. [41]; upper left corner) with location and synthetic sedimentary logs (modified, from Di Giulio and Galbiati [42]) of the three outcrops of the Cappella della Valle $\mathrm{Mb}$. with average paleoflow direction (arrows). The red box indicates the studied outcrop.

The outcrop detailed in this study (Figure 1) is one of the three outcrops of the Cappella della Valle $\mathrm{Mb}$. $(\mathrm{CdV})$, a channelized turbidite sandstone belonging to the late Oligocene Gremiasco Formation [40,41]. Up to $40 \mathrm{~m}$ thick and $200 \mathrm{~m}$ across, CdV represents the infill of a turbidite channel [41,42] entrenched into hemipelagic marlstones (cf. with Rigoroso Marls of Bellinzona et al. [43]).

Referred to as part of the Antognola Fm., the studied outcrop has been already object of sedimentologic, petrographic and diagenetic investigations in the 90's. Cibin et al. [24] described the $\mathrm{CdV}$ sandstones as immature litharenites, showing there is no obvious difference in detrital grain composition and heavy mineral assemblage between concretions and host sandstone. These same authors also noted an intergranular volume (IGV) difference between calcite-cemented concretions and host sandstones of up to $5 \%$ (with average IGV of $11.6 \%$ ), suggesting that mechanical compaction of the uncemented host continued after calcite cementation. Mc Bride et al. [1] evaluated the shape, size and spatial distribution of 40 concretions measured on the accessible parts of the outcrop concluding that, except for a few (17\%) elongate, bed-parallel concretions, most of them $(83 \%)$ are sub-equant to equant and there is no evident predictability to their shape and occurrence. Lastly, based on in-depth geochemical and stable isotope investigation of the calcite cements, Milliken et al. [44] indicated that the carbonate ions for cementing the concretions might have been derived from both the carbonate clasts and bioclasts contained in the sandstone and the marlstones surrounding $\mathrm{CdV}$, suggesting ions diffusion and precipitation from deeply circulated meteoric waters at burial depths in the range $1250-1550 \mathrm{~m}$.

\section{Materials and Methods}

The 3D outcrop model used to make this study was generated with photogrammetry techniques from digital imagery acquired with a SonyA6000 mirrorless camera (Figure 2a) featuring a $16 \mathrm{~mm}$ lens and a 24.3 Megapixel CMOS sensor $(6000 \times 4000$ pixels; pixel size of ca. $4 \mu \mathrm{m})$. 


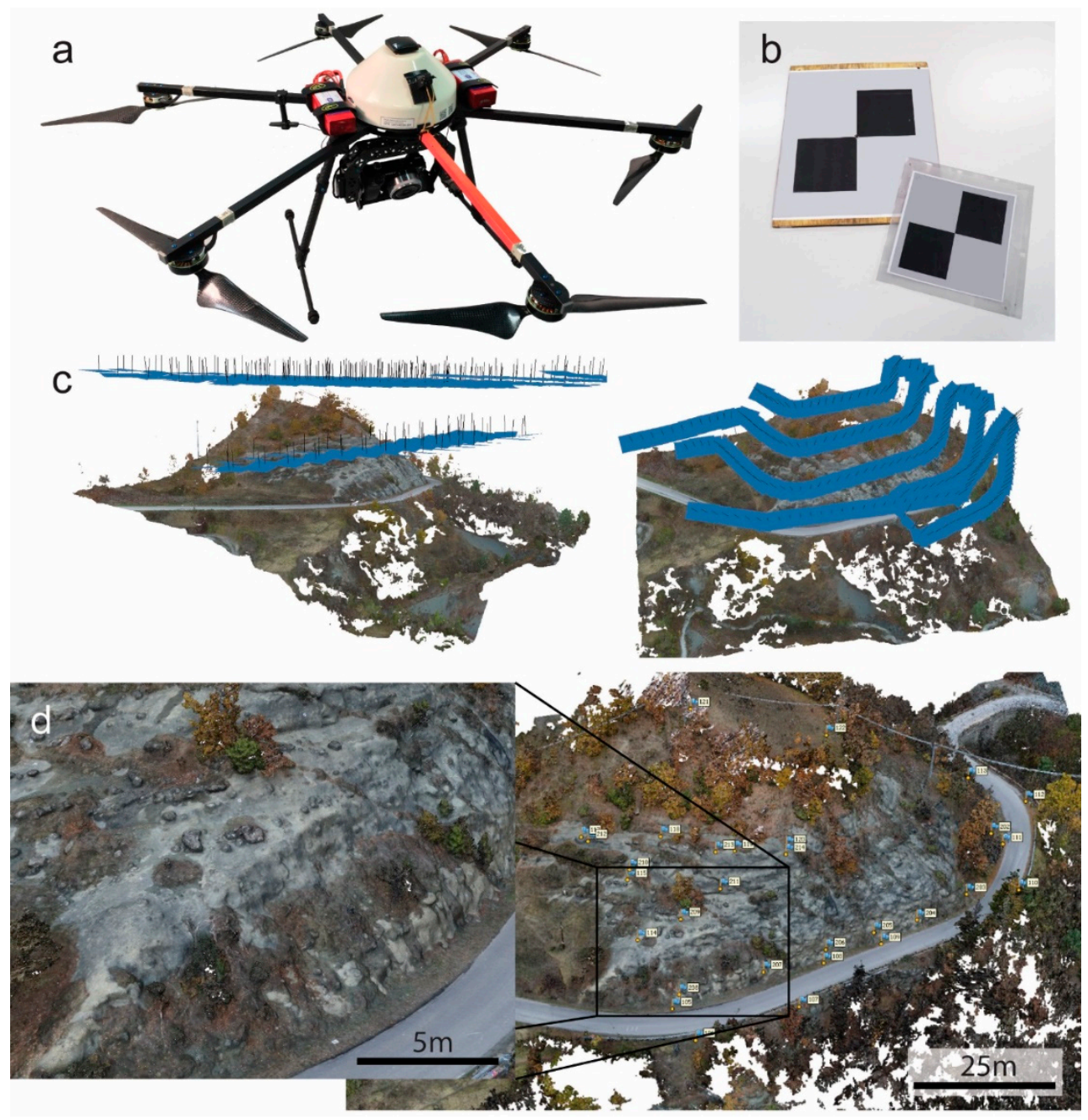

Figure 2. (a) The HEXA-PRO multicopter unmanned aerial system equipped with the Sony A6000 camera used for the acquisition of aerial photogrammetric blocks; (b) Cardboard target used as ground control points (GCPs); (c) The UAV flights performed for acquiring the nadiral (left) and oblique (right) photogrammetric blocks; (d) the dense point cloud with location of GCPs (right) and detail (left) showing some concretions exposed along the dip slope.

Before image acquisition, 34 artificial markers (Figure 2b) were deployed on the outcrop to serve as ground control points (GCPs), and their coordinates measured with an integrated total station and GNSS survey. The coordinates of an additional set of 9 points were measured from the sporadic outcrops of the CdV base.

The outcrop morphology required acquiring multiple photogrammetric blocks to achieve full image coverage and the desired detail. These included two nadiral (i.e., downward looking camera) and three oblique (camera tilted by $45^{\circ}$ from nadir) aerial blocks (Figure $2 \mathrm{c}$ ) acquired from the HEXA-PRO multicopter UAV of the University of Pavia (Figure 2a), and a terrestrial block acquired from the road, which collectively yielded more than 1000 images with an average ground sampling distance less than $1 \mathrm{~cm}$.

After undistorting images with the prescribed camera calibration procedure and orienting blocks using GCPs, a dense cloud of 118 million points with $(x, y, z)$ coordinates was extracted using Agisoft Photoscan ${ }^{\mathrm{TM}}$, with an average point spacing of ca. $1.6 \mathrm{~cm}$, which is well below the typical diameter of the smallest concretions observed at outcrop.

The point cloud covers most of the CdV channel-fill sandstone except for its margins (Figure 2d), whose view was obstructed by numerous trees and the roadway. After tilting the point cloud for 
restoring bedding to horizontal, a photo-textured mesh was generated and imported into a 3D data visualization and interpretation software (Virtual Reality Geology Studio, VRGS hereafter; [45]) for point-picking the boundaries of a total of c. 1700 concretions and the few detectable bedding surfaces.

Interpretations made in VRGS were then imported into ArcGIS10. $2^{\circledR}$ and Petrel $2017^{\mathrm{TM}}$ for assessing lengths, spatial clustering and volume proportion of concretions.

Throughout this manuscript, the terms length $(l)$ and width $(w)$ will be used to refer to the maximum and minimum lengths of the concretion measured along two orthogonal axes resting in the bedding plane. In turn, thickness $(t)$ will be used to refer to the length measured perpendicular to bedding. Ratios between these lengths are used to classify concretions following the convex shape categories after [46] reported in Table 1.

Table 1. Explanation of convex shape classes after [46]; $l, w$ and $t$ are length (maximum axis), width (intermediate axis) and thickness (minimum axis, perpendicular to bedding), respectively.

\begin{tabular}{ccccc}
\hline Shape Category & $\begin{array}{c}\text { Intermediate and } \\
\text { Long Axes }\end{array}$ & $\begin{array}{c}\text { Intermediate and } \\
\text { Short Axes }\end{array}$ & Explanation & Example \\
\hline equant & $0.67<\mathrm{w} / \mathrm{l}<1$ & $0.67<\mathrm{t} / \mathrm{w}<1$ & all dimensions are comparable & ball \\
oblate ${ }^{1}$ & $0.67<\mathrm{w} / \mathrm{l}<1$ & $\mathrm{t} / \mathrm{w}<0.67$ & thickness is shorter & pancake \\
prolate & $\mathrm{w} / \mathrm{l}<0.67$ & $0.67<\mathrm{t} / \mathrm{w}<1$ & length is much longer & cigar \\
bladed & $\mathrm{w} / \mathrm{l}<0.67$ & $\mathrm{t} / \mathrm{w}<0.67$ & all dimensions very different & belt \\
\hline \multicolumn{7}{c}{${ }^{1}$ include sub-equant and elongate shapes after [1]. }
\end{tabular}

Because most of the outcrop is too steep to be walked out (Figure 2), sedimentary facies description could only be made along three transects (Figure 3). This was accomplished by measuring stratigraphic heights of base and top of turbidite event beds with a Jacob staff and noting lithology (i.e., sandstone vs. mudstone), sedimentary structures and changes in average grain size and sorting. A set of 74 rock samples was collected by using either a hammer or a core drill, targeting both the host sandstones and the concretions of $\mathrm{CdV}$, as well as the marlstone above, below and within (i.e., capping turbidite event beds or forming rip-up clasts) the studied sandstone.

The CdV sandstones and surrounding hemipelagic marlstones were investigated through petrographic analysis of 48 thin sections.

To identify cement and accessory mineral type and composition, 9 polished slabs and a few freshly broken surfaces previously coated with gold and 5 carbon-coated polished thin sections were imaged with a Cambridge Stereoscan 360 scanning electron microscope (SEM) equipped with EDS and operating at a voltage of $20 \mathrm{kV}$ and a distance of $15 \mathrm{~nm}$.

Cathodoluminescence was performed on polished thin sections to evaluate the luminescence of calcite cements and carbonate lithics using a MK 5-2 luminoscope by Cambridge Image Technology $\mathrm{Ltd}$. (beam voltage of 10 to $16 \mathrm{kV}$; beam current of 200 to $600 \mu \mathrm{A}$; vacuum gauge of 50 to 70 millitor).

The bulk mineralogy was determined by X-ray powder diffraction (XRD) of 6 whole-rock powders using a Philips X'Pert MPD high temperature chamber powder diffractometer and the dedicated Panalytical X'Pert High Score software for qualitative analysis of crystalline phases. The mineralogy of detrital and authigenic clay minerals was determined by whole-rock XRD analyses on oriented slides made from the $<2 \mu \mathrm{m}$ fraction (glycolated and unglycolated; see methods in [47]) and further investigated on two thin sections from the host sandstones by synchrotron analyses on sample spots.

Oxygen and carbon isotope analyses were made on 60 whole-rock powders extracted with a dental microdrill and reacted with phosphoric acid at $70{ }^{\circ} \mathrm{C}$ by using a Thermo Fisher Scientific Delta Plus XP continuous flow mass spectrometer, equipped with a Gasbench II on-line gas preparation and introduction system. The carbon and oxygen isotope compositions are expressed in the conventional delta notation against the international standard V-PDB. Standardization was conducted using laboratory calcite standards calibrated against the NBS-18 and IAEA-603 standards. Reproducibility was better than $\pm 0.1 \%$ o for both $\delta^{13} \mathrm{C}$ and $\delta^{18} \mathrm{O}$. 
The carbonate content of the hemipelagic marlstones was determined by weight loss upon reaction with $10 \% \mathrm{HCl}$. Sandstone porosity was estimated using the open source software ImageJ by determining area percentages of pore space on thin section and SEM photomicrographs.

The same image analysis procedure was used to determine area percentages of calcite cement of 42 cathodoluminescence photomicrographs taken from 12 thin sections of as many concretions.

Except for synchrotron data, which were acquired at the European Synchrotron Radiation Facility (Grenoble, France), petrographic, mineralogical and geochemical laboratory analyses were all conducted at the Earth Sciences Department of the University of Milan (Italy).

\section{Results}

\subsection{Channel-Fill Geometry and Sedimentary Facies}

Where stratigraphically deepest, the CdV base is ornamented with large flutes casts up to $15 \mathrm{~cm}$ deep witnessing palaeoflow toward the E-NE (mean direction is ca. $70^{\circ}$; Figures $3 \mathrm{a}-\mathrm{c}$ and $4 \mathrm{a}$ ) and deep substrate erosion. The few outcrops of the $\mathrm{CdV}$ base line up onto a paraboloid cylinder-like surface with axis parallel to mean palaeoflow, suggesting a nearly axis-symmetric cross-section ca. 250-m wide and aspect ratio (thickness/width) of ca. 1:7-1:8 (Figure 3a,b).

In channel-axis locations (e.g., Log 1 in Figure 3a), the channel-fill is initiated with ca. $5 \mathrm{~m}$ of amalgamated normally graded beds of fine-medium conglomerates and sandstones, rich in marlstones rip-ups and well-cemented (Figure 4a). Up-section, CdV is composed of a few amalgamated bedsets with thickness in the range 4-7 m. Typically, these bedsets start with poorly sorted very coarse sandstones with a range of traction carpets and planar-parallel lamination (Figure $4 \mathrm{~d}$,e; cf. with facies F7 of Mutti [48]) which may grade upward into normally graded medium sandstones (cf. with facies F8 of Mutti [48] and Ta division of [49]) forming 0.5-3 m-thick event beds with scoured non-planar bases (Figure $4 \mathrm{~b}-\mathrm{e}$ ). Because basal scours show depth less than $1 \mathrm{~m}$ and cross-flow width of several tens of centimeters and are filled in by coarse-lags typically rich in mudstone rip-ups (Figure $4 \mathrm{~d}$ ), the lower part of bed sets has a highly heterogeneous, seemingly disorganized structure. The common micropaleontological content and XRD composition (see Section 3.4) of the mudstone rip-ups and the marlstones below and above CdV (Figure 3c), along with similar carbonate content variability, suggest the rip-ups were eroded from a marly substrate similar to that exposed at outcrop.

Up-section, basal scouring becomes less severe and rip ups relatively less abundant, resulting in a greater preservation of fine-grained laminated tops and mud caps and, ultimately, a more layered facies architecture (e.g., bed sets III and IV; Figure 3a). Importantly, reaction to $\mathrm{HCl}$ suggests turbidite mud caps have marly composition. The same change occurs from axis to off-axis locations (Figure $4 b$ ), accompanied by a reduction of average grain size. The $\mathrm{CdV}$ top is marked the sharp superimposition of marlstones intercalated with drift-laminated thin bedded fine-grained turbidites and is typically less cemented than the CdV base (Figure 4f), possibly reflecting its finer grained and less porous nature.

\section{Interpretation}

The geometrically simple and axis-symmetric channel-form of $\mathrm{CdV}$, as well as its flat top, suggests it represents a relatively short-lived feature resulting from a single phase of incision and infilling. Vertical changes in sedimentary facies would indicate an early by-pass phase with deposition of coarse lags from hyper-concentrated gravelly flows, followed by aggradation and facies backstepping after sedimentation from a range of high to low density, waning turbidity currents. Within amalgamated bed sets, basal scours and the overlying coarse-grained mud-clast rich facies represent individual lowest-rank channel-forms and their fills, respectively, whereas preserved mud caps of off-axis settings constitute intra-channel shales [50], likely to pass laterally to channel-drapes [51]. Overall, CdV is best interpreted as the single-storey fill of a low-sinuosity incisional channel crossing a low-gradient slope [52]. 


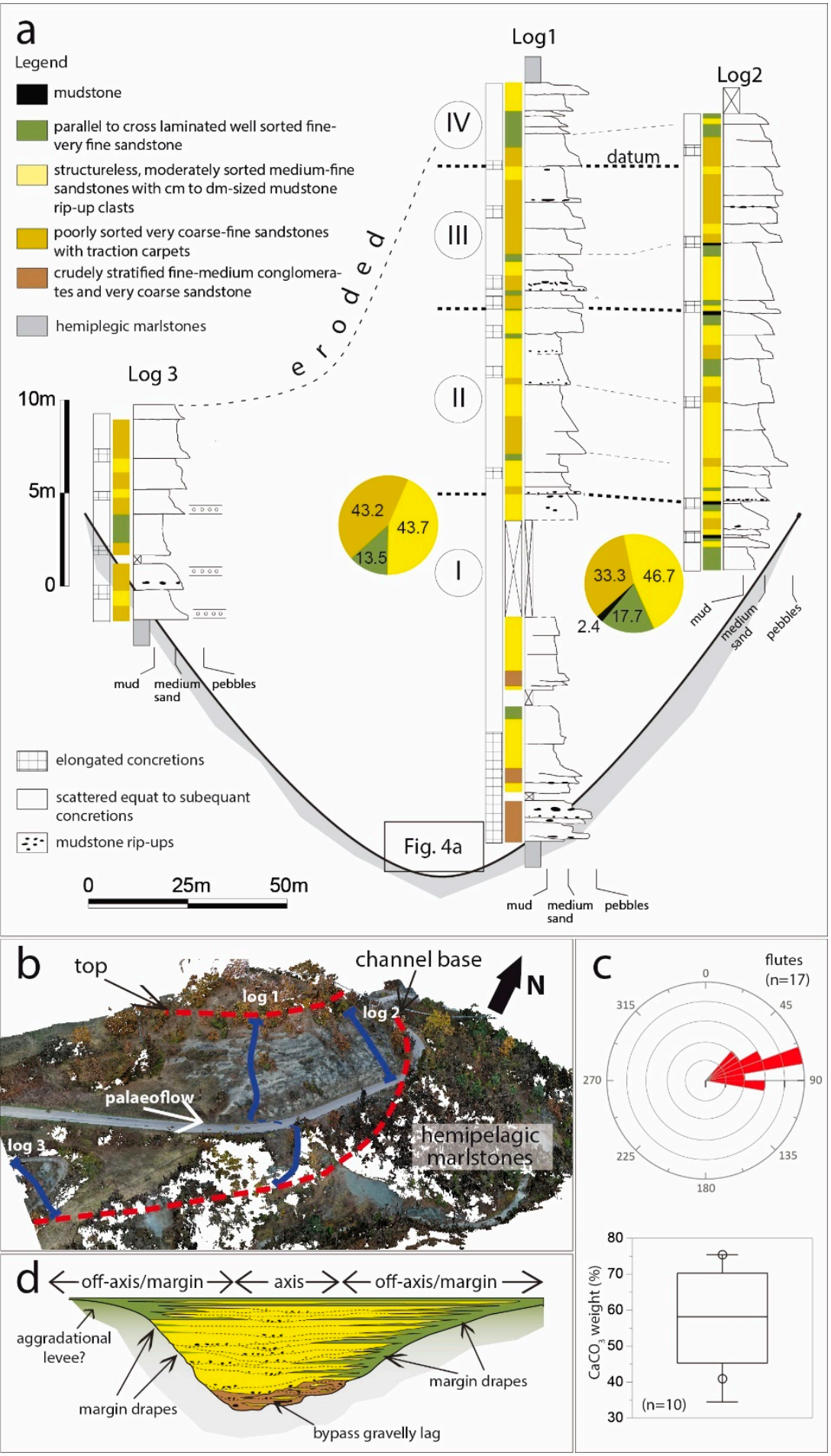

Figure 3. (a) Correlation of sedimentary logs with boundaries of bed sets I-IV discussed in the text, facies and concretion types (left-hand side of logs). Pie charts indicate facies percentages in the correlative interval of logs 1-2; (b) View of the photogrammetric model of the Cappella della Valle outcrop (CdV) with base and top boundaries and location of the sedimentary logs; (c) Rose plot of paleoflow direction from flutes casts from the CdV base and box-plot of calcimetry of marlstone rip-ups and hemipelagic marlstones above and below $\mathrm{CdV}$ (circles); (d) Likely depositional model for CdV (modified, after McHargue et al. [51]). 

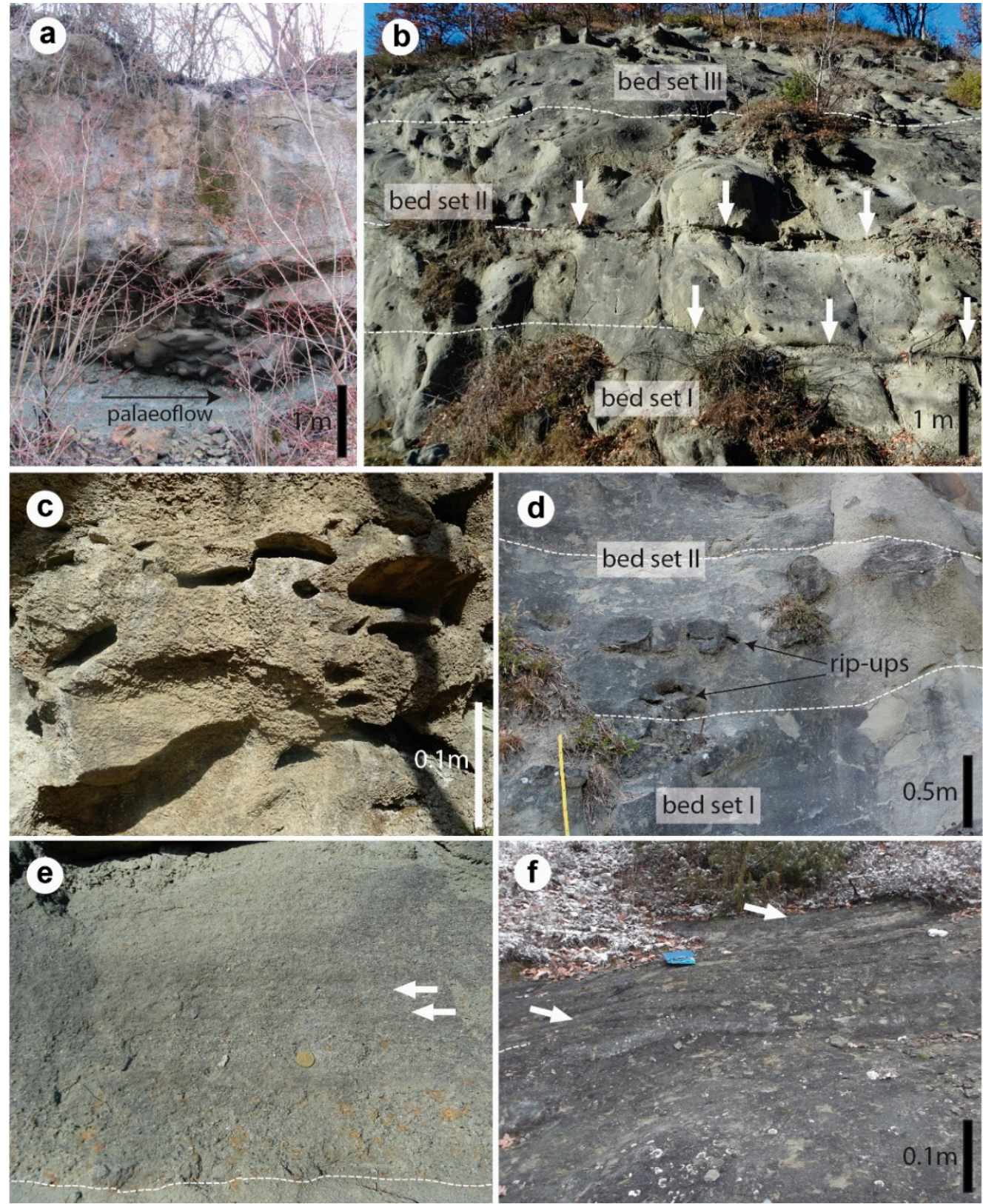

Figure 4. (a) Flute casts from the channel-fill base in log 1 indicating average palaeoflow toward W-NW (see Figure 3a). Note the well-cemented nature of the lowermost part of CdV; (b) amalgamation surfaces (dashed lines) passing laterally (to the right, i.e., toward the channel margin) to preserved turbidite mud caps (arrows); (c) Large marlstone rip-ups within completely cemented sandstone bed from the lowermost part of CdV; (d) Amalgamated sandstone beds with a range of faint to well-developed parallel lamination; (e) coarse infill of a basal scour with mm-scale marlstone rip-ups surrounded by a yellowish weathering aura, followed upward by traction carpets (arrows); (f) Arrows indicate medium(below) to small- (above) scale bed forms from the upper part of bed set IV (paleoflow toward the right). Note the poorly cemented nature of the deposit.

\subsection{Concretion Shapes}

Because only a few concretions fully emerge from the host sandstones revealing their 3D shape, assessment of concretion shape must proceed studying axes length ratios separately for the horizontal and the vertical planes. This can be done focusing first on the width-to-length ratio of those concretions 
exposed along the gently sloping parts of the outcrop (corresponding to the dip-slope of turbidite beds, Figure 5a), and then studying concretion thickness along steep outcrop faces (Figure 5).

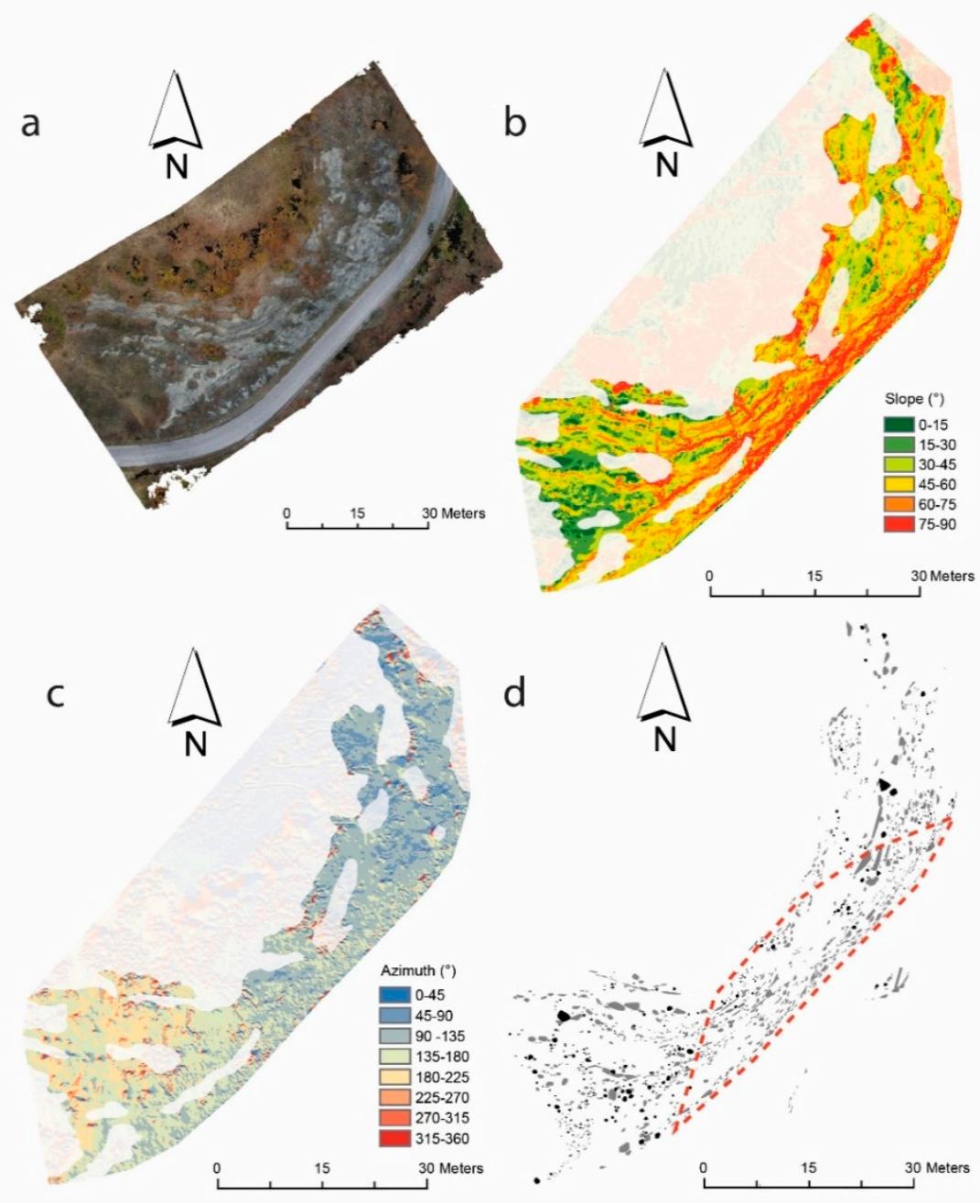

Figure 5. (a) View from above of the point cloud with outlines of the two outcrop faces used for computing concretion pattern spatial statistics; (b) Slope direction and (c) slope angle of the digital surface model obtained from the point cloud. The transparent white polygons represent poor outcrop exposure or covered areas; (d) Concretion boundaries extracted from the VRGS software and used to assess width-to-length (black) and thickness-to-width (grey) ratios. The dashed red polygon highlights the near vertical outcrop face used for evaluating the spatial clustering of concretions (see Section 3.3).

Plotting the width vs. length of the boundaries of the subset of ca. 270 concretions emerging from the dip slope of beds shows the two measured lengths are positively correlated and well fitted (coefficient of determination $\mathrm{R}^{2}=0.98$ ) with a linear regression model (Figure 6a) whose residuals are normally distributed around a mean close to 0 (see insert in Figure 6a). It is noteworthy that the concretion length orientations appear to broadly cluster in the azimuth range $20-135^{\circ}$, i.e., the same orientation range of most of the outcrop (Figure 6b), suggesting the outcrop morphology might have resulted in overestimation of this length. Also, the absence of a well-defined cluster of length orientation indicates concretions are unlikely to possess a preferred orientation. It can be thus concluded that the linear regression of Figure 6a provides an estimate of the characteristic $w / l$ (i.e., the angular coefficient $\approx 0.76$ ) of concretions that, because of a likely overestimation of $l$, is way conservative (Table 1 ) for excluding prolate and bladed shapes with their long axis laying in the bedding plane (Figure $6 \mathrm{c}$ ). 
a

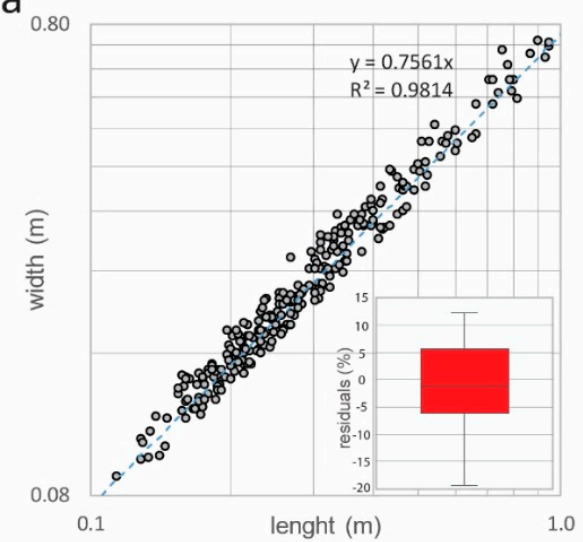

C

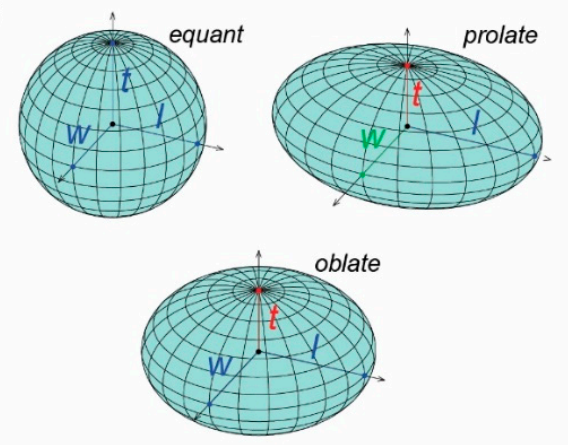

b
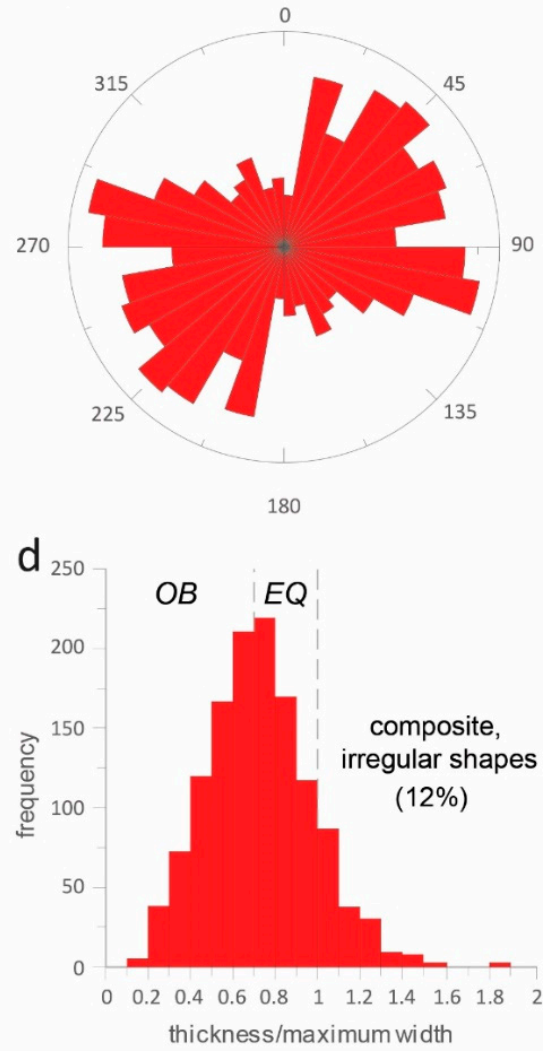

Figure 6. (a) Scatter plot (logarithmic axes) of width $(w)$ vs. length ( $l)$ of 269 concretions from the dip-slope parts of the outcrops (see Figure 5c) with linear fit. Note that the coefficient of correlation $R^{2}$ indicates a strong positive correlation and normally distributed residuals (as percentage of concretion length in insert box plot); (b) Rose diagram showing the azimuth orientation of the lengths (i.e., maximum axes) of concretions resting in the dip slope parts of the outcrop; (c) Idealized representation of convex shape classes of Table 1 where $l, w$ and $t$, denote length (maximum axis), width (intermediate axis) and thickness (minimum axis), respectively; (d) Histogram of thickness-to-maximum width ratio of 1315 concretions exposed along steep outcrop faces with $t / w$ threshold values (dashed lines) for oblate (OB), equant (EQ) and composite concretions with $t>w$ (ca. $12 \%$ of the population).

Because concretions do no show a preferred orientation of 1 , when considering the steep parts of the outcrop there is uncertainty on whether the length of concretion boundaries measured parallel to bedding represented either their $l$ or $w$. However, since, by definition (Table 1 and Figure $6 \mathrm{c}$ ), $l$ is equal or greater than $w$, a cautious assumption can be made that this length represented the maximum possible width (maximum width, hereafter) of concretions.

The histogram of $t / w$ of concretions protruding from the steep parts of the outcrop (Figure $6 \mathrm{~d}$ ) is slightly right-skewed with a mean close to 0 , highlighting that nearly $90 \%$ of the sample population has thickness smaller than maximum width. When checked on the outcrop, the concretions with $t / w>$ 1 (i.e., the right tail of histogram of Figure $6 \mathrm{~d}$ ) turned out to be mostly of composite nature, resulting from coalescence of smaller variously shaped concretions (Figure $7 \mathrm{a}-\mathrm{c}$ ), and subordinately associated with fracture joints (Figure $7 \mathrm{~b}, \mathrm{c}$ ), thus excluding presence of primary prolate shapes with long axis perpendicular to bedding. 

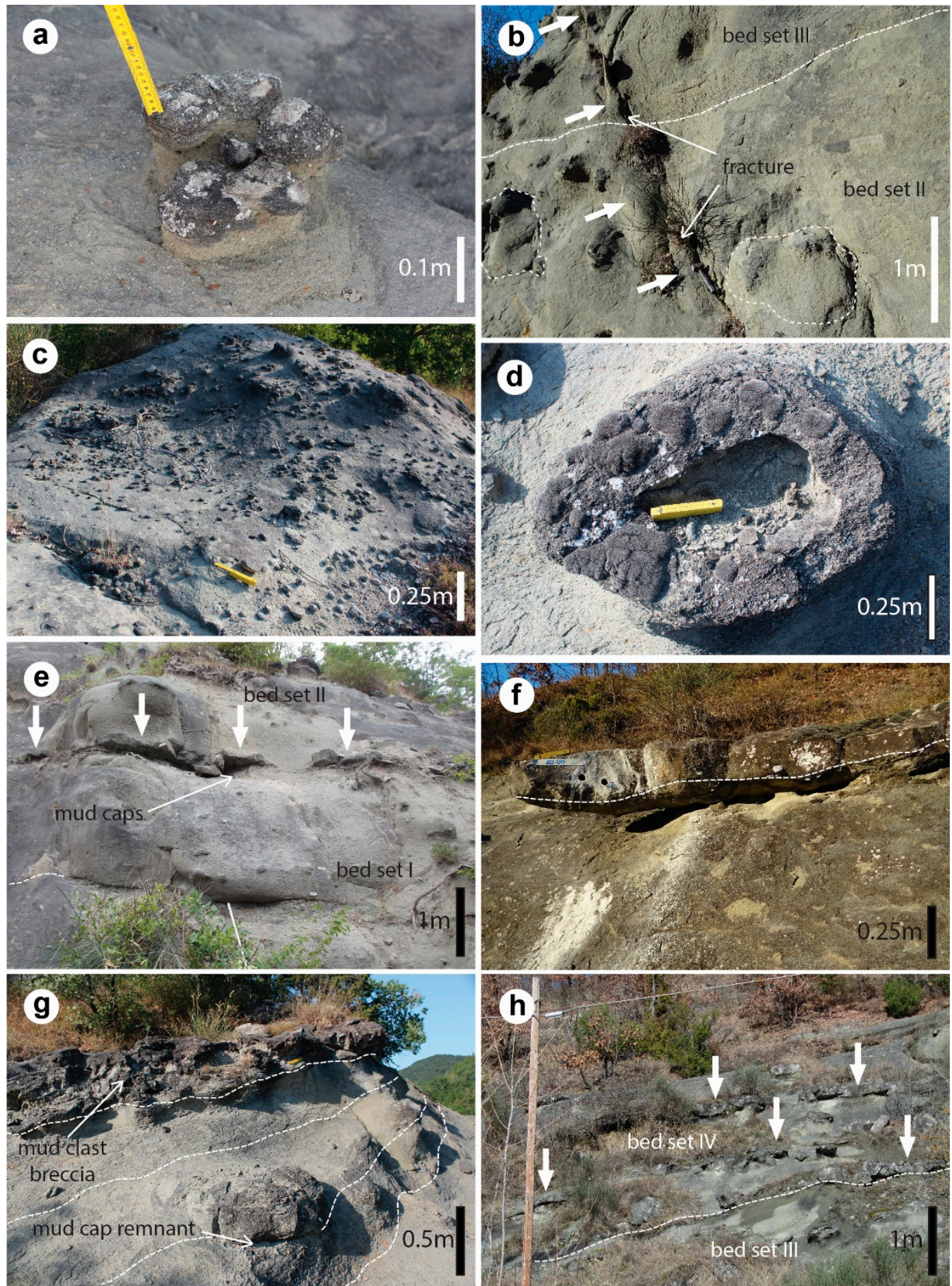

Figure 7. (a) Coalescing cm-scale equant concretions; (b) Elongated concretions (arrows) developed parallel to fractures and composite shapes (dashed white line) resulting from coalescence of smaller concretions; (c) cm-scale concretions from the upper finer grained part of bed set II; (d) Equant concretion with a marlstone rip-up at its core; (e) and (f) show highly elongated strata bound concretions (indicated by arrows in e) developed either above a turbidite mud cap and straddling an amalgamation surface, respectively. In (e), note the contrastingly poorly cemented nature of the base of the uppermost bed from bed set I despite its vertical association with a mud cap; (g) Composite concretions developed across an amalgamation surface (below) and marlstone clast breccia forming a highly elongated concretion several m-long; (h) highly elongated concretions (highlighted by arrows) from the upper axial part of CdV. 
The remainder concretions split in similar proportions of equant (46\%) and oblate (42\%) shapes (Figure $6 \mathrm{~d}$ ) whose volume $(V c)$ can be estimated assuming an ellipsoidal 3D shape and $l \approx w$ by calculating:

$$
V_{c}=\frac{4 \pi}{3} \times \frac{l}{2} \times \frac{w}{2} \times \frac{t}{2}
$$

Equant concretions fall in a wide size range, from $\mathrm{cm}$ to $\mathrm{m}$-scale (Figure $7 \mathrm{a}, \mathrm{c}, \mathrm{d}$ and Figure $8 \mathrm{a}, \mathrm{b}$ ). Typically, cm-scale equant concretions occur in the upper finer-grained part of beds (Figure 7c). Larger equant concretions are instead found close to bed bases, developed around marlstone rip-ups with medium to high sphericity (Figure 7c).

a

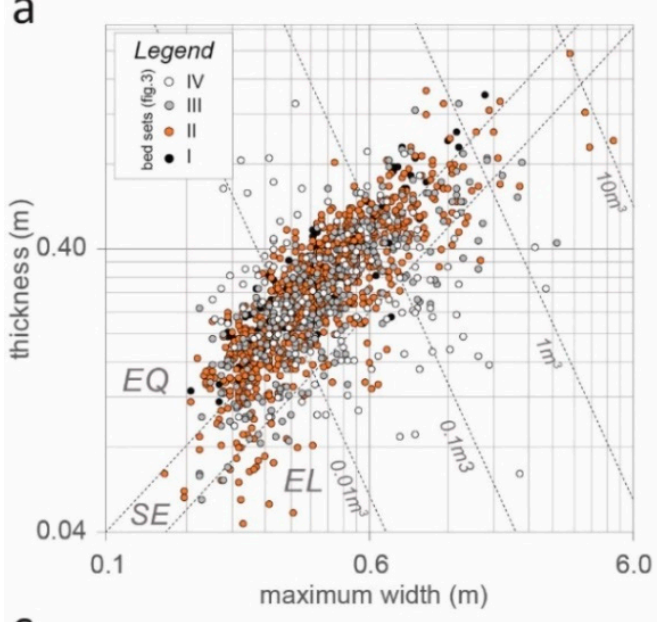

C

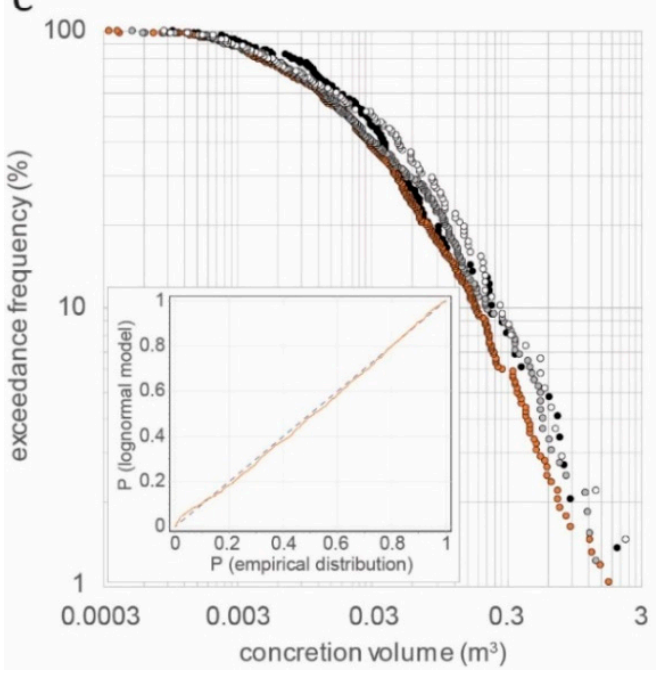

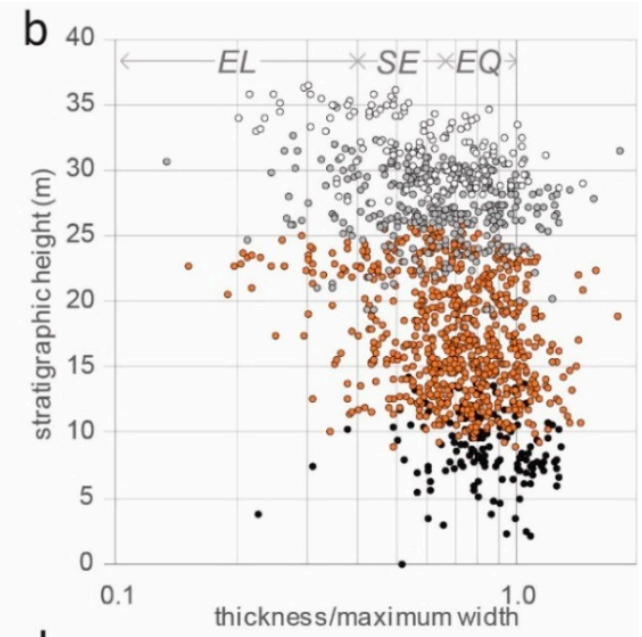

d

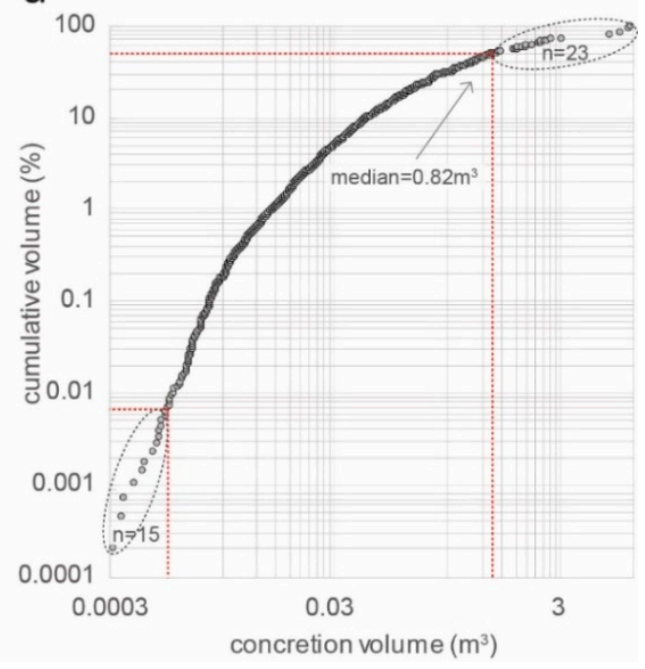

Figure 8. (a) Scatter plot of maximum width vs. thickness (logarithmic axes). The dashed lines delimit fields of equant (EQ), sub-equant (SE) and oblate (OB) shapes and volume rages; (b) Scatter plot of thickness to width ratio (logarithmic axis) vs. stratigraphic height; (c) Exceedance probability plot (logarithmic axes) of concretion volumes for bed sets I-IV with insert probability-probability indicating a lognormal model represents a good fit for the observed statistical distribution of concretion volumes; (d) Cumulative volume vs. volume (logarithmic axes) of concretions. Note how concretions with volume greater than $0.82 \mathrm{~m}^{3}$ account for $50 \%$ of the total cemented sandstone volume, whereas concretions with volume less than $0.001 \mathrm{~m}^{3}$ represent less than $0.0067 \%$ of the total volume. Data from 1286 concretions from bed sets I to IV (see legend) protruding from the steep to near-vertical outcrop faces of CdV.

Following the definition of McBride et al. [1], oblate shapes can be further distinguished into sub-equant and elongated ones for $w / t$ below and above 2.5, respectively (Figures $6 \mathrm{~d}, 7$ and 8 ). 
Some sub-equant to elongated concretions possess parallelepipedal marlstone rip-ups at their core, suggesting the shape of these carbonate-rich intraclasts can condition the shape of the associated concretions. Representing the $9 \%$ of the sample population (Figure $6 \mathrm{~d}$ ), most of the elongated shapes are strata-bound concretions developed either above turbidite mud caps (Figure 7e) or straddling amalgamation surfaces (Figure 7f).

Elongated shapes often extend over the whole thickness of the containing bed resulting in completely cemented beds (Figure 7f). In one single case, a nearly tabular concretion several meters-long formed within a marlstone clasts breccia bed (Figure 7g). It is worth nothing the tendency of larger concretions (i.e., greater than $1 \mathrm{~m}^{3}$ ) to be preferentially sub-equant to elongated (Figure 8a), as well as the up-section increase of abundance of oblate shapes, with most of the elongated concretions belonging to the uppermost part of bed set II and bed sets III-IV (Figure 8b).

The exceedance probability plot of Figure $8 \mathrm{c}$ shows how subsequent bed sets possess similar statistical distributions of concretion volumes, which are adequately fitted with a lognormal model (see the insert probability-probability plot in the same figure).

Also, it should be noted that that the $50 \%$ of the cumulative concretion volume is made by the few of them (23!) having volume greater than $0.82 \mathrm{~m}^{3}$ (Figure $8 \mathrm{~d}$ ), most of which are elongated concretion of completely cemented beds (e.g., Figure 7e-h).

\subsection{Concretion Spatial Distribution}

Sub-equant to elongated concretions are few to absent in the lower part of $\mathrm{CdV}$, whereas their frequency becomes appreciable up section (Figure 9a). A similar trend is observed moving from channel-axis to off-axis locations (Figure 9b), seemingly correlating to incomplete bed amalgamation and consequent increased proportion of preserved mud caps (see sedimentary facies pie charts in Figures 3 and $7 \mathrm{e}-\mathrm{h}$ ).

The proportion of concretion vs. host sandstone volume was estimated by upscaling the interpreted concretions to a very fine-scale grid (cell size of $0.1 \times 0.1 \times 0.1$ ). Although it can be argued that this may result in underestimating $\mathrm{cm}$-scale concretions and thus the cumulative volume of cemented vs. host sandstone, it must be born in mind that concretions smaller than the cell size (i.e., $0.001 \mathrm{~m}^{3}$ ) represent less than $0.01 \%$ of the total volume of the observed concretions (Figure $8 \mathrm{~d}$ ).

While the gross cumulative volume of the $\mathrm{CdV}$ concretions is close to ca. $22 \%$ of the total investigated volume, comparing the concretion cumulative volume fraction of channel-axis and off-axis to marginal settings suggests calcite cementation had affected slightly greater volumes (ca. $6 \%$ ) away from the channel axis. Proportion curves of Figure $9 \mathrm{~d}$ show a clear stratigraphic cyclicity in fraction of cemented vs host sandstone, which mirrors the location of concretion within the containing turbidite beds and, at a larger scale, the bedding pattern. Because of the non-planar erosive contacts between subsequent event beds, comparison of proportion curves calculated in axial and off-axis to marginal locations appear not to correlate at most stratigraphic heights, reflecting the uneven concretion distribution and, ultimately, a poorly layered facies architecture. 
a
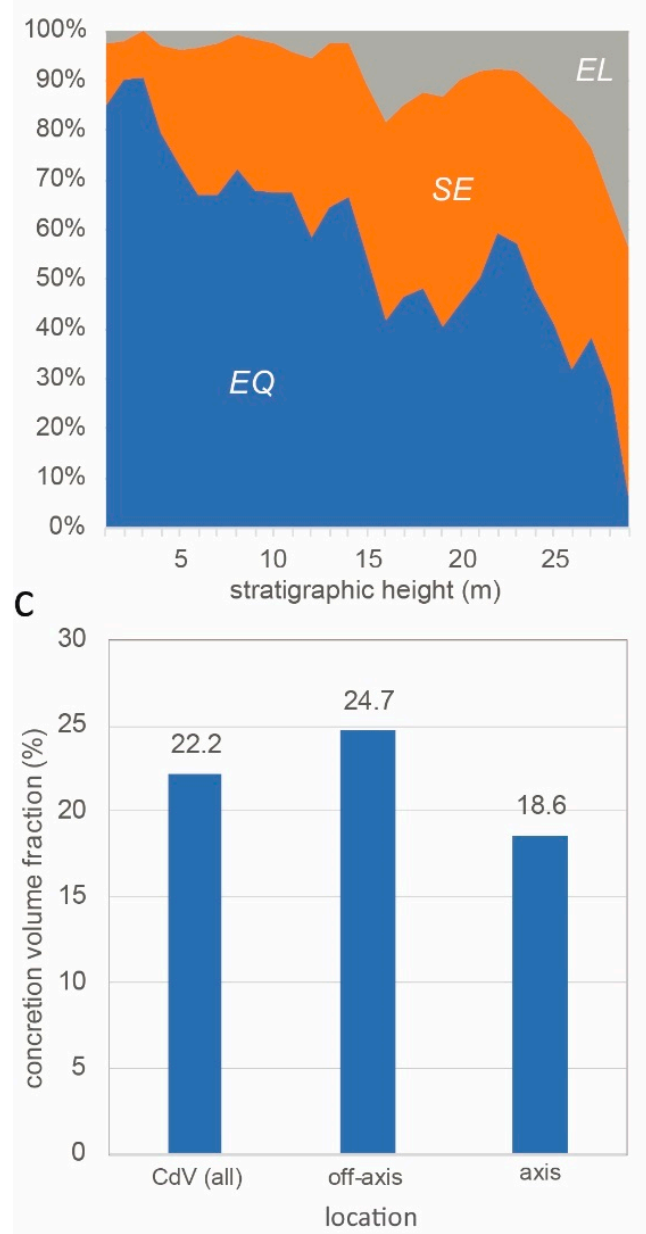

b

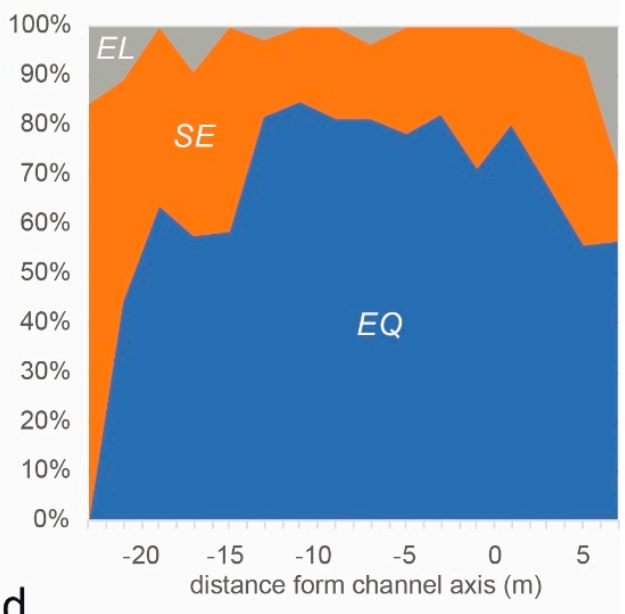

d

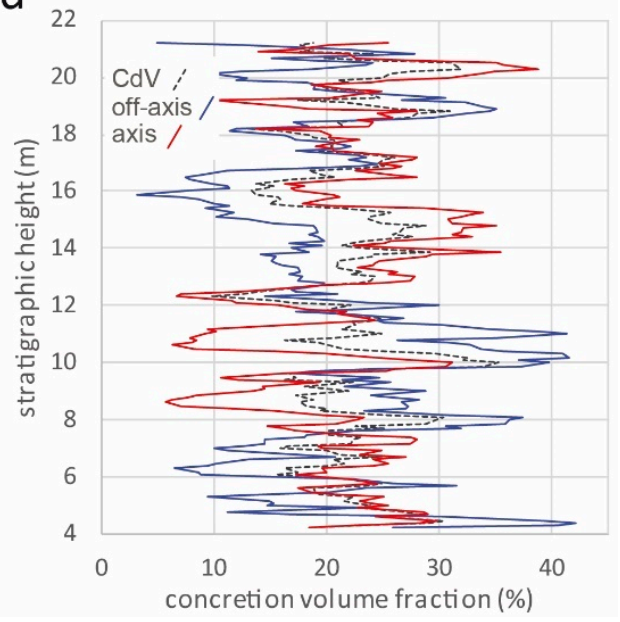

Figure 9. (a) Variability of abundance of equant (EQ), sub-equant (SE) and elongated concretions with respect to stratigraphic height (a) and distance from channel axis (b); (c) Bar chart showing cumulative volume fraction of concretions in the whole studied outcrop, and off-axis and channel-axis locations; (d) Vertical proportion curves of concretion showing the stratigraphic variability of concretion volume fraction.

The 2-D pattern of concretion spatial distribution was assessed on three test areas devoid of cover from the near vertical face of the studied outcrop (T1 to T3 in Figure 10a) using Average Nearest Neighbour statistics (ANN; [53]), an inferential statistic method testing the hypothesis of complete spatial randomness (null hypothesis, hereafter). ANN measures the distance between each centroid and its nearest neighbour's location and return the ratio of the average of all measured distances $\left(\bar{D}_{O}\right)$ to the average distance of a randomly distributed point set $\left(\bar{D}_{E}\right)$ of comparable size and extent. If the ratio:

$$
A N N=\frac{\bar{D}_{O}}{\bar{D}_{E}}
$$

is less than 1, the pattern exhibits clustering. Conversely, $A N N$ greater than 1 indicates a trend toward dispersion. Yet, the calculated ANN should be interpreted in conjunction with its standard deviation (or z-score) and the linked probability (p-value) that the observed pattern could be the result of random chance. It can be noted how very high or very low (negative) $z$-scores, associated with very small $p$-values, are found in the tails of the statistical distribution typifying a random process (Figure 10b), thus indicating the observed pattern is very unlikely (i.e., very small probability) to be the result of random chance. It is important to note that in a random spatial distribution clusters may still be present locally, though being not statistically significant. 
Table 2. Results of the Average Nearest Neighbour $(A N N)$ statistics. $A N N$ is the index described by Equation (2), the z-score is the ANN standard deviation and the $p$-value is the significance level of results, i.e., the probability that the null hypothesis (complete spatial randomness) is erroneously rejected. Interpretation assumes a confidence of $95 \%$.

\begin{tabular}{ccccccccc}
\hline Test Area & $\overline{\mathbf{D}}_{\boldsymbol{O}}$ & $\overline{\mathbf{D}}_{\boldsymbol{E}}$ & $\boldsymbol{A N N}$ & $\boldsymbol{z}$-score & $\boldsymbol{p}$-Value & Area $\mathbf{( m}^{\mathbf{2}} \mathbf{)}$ & $\mathbf{n}^{\mathbf{1}}$ and Density $\mathbf{( n / m )}$ & Interpretation \\
\hline T1 & 0.72 & 0.63 & 1.14 & 3.01 & 0.002 & 195 & $135 ; 0.69$ & Dispersed \\
T2 & 0.60 & 0.54 & 1.10 & 2.47 & 0.01 & 204 & $172 ; 0.84$ & Dispersed \\
T3 & 0.49 & 0.50 & 1.00 & 0.02 & 0.97 & 199 & $200 ; 1.00$ & Random \\
\hline \multicolumn{8}{c}{ 1 number of }
\end{tabular}

${ }^{1}$ number of concretions present within the test area.

Results of $A N N$ are reported in Table 2 along with interpretation for a confidence level of 0.95 that is, accepting a 5\% probability of erroneously rejecting the null hypothesis. Note that, the T1, T2 and T3 test areas have very similar size (ca. $200 \mathrm{~m}^{2}$ ) but different location, namely middle, upper left and lower right of the near vertical outcrop wall. T1 and T2 returned ANN greater than 1 and $p$-values of 0.002 and 0.01 , respectively, suggesting a concretion pattern of a dispersed type very unlikely (less than $5 \%$ probability!) to result from random chance.

Conversely, with a p-value of 0.97 , T3 does not appear to be significantly different from random. Though results would show that concretions are not significantly clustered spatially, it should be borne in mind that in $A N N$ neither size and shape of concretions nor their spatially anisotropic distribution are accounted for. This limitation of $A N N$, common to all methods based on neighbours statistics (e.g., Ripley's K Function) is evident especially when considering large-size, elongated concretions (Figure 10c), which tend to cluster along bedding (e.g., Figures 7e-h and 10c) resulting in the uneven vertical distribution of cemented sandstones seen in Figure 9d.

\subsection{Petrography}

The studied CdV sandstones are immature to submature litharenites [54], poorly to moderately sorted with grain size ranging from fine $(50-200 \mu \mathrm{m})$ to coarse sand $(0.5-1 \mathrm{~mm})$, with sparse lithic fragments up to $3 \mathrm{~mm}$ and $\mathrm{mm}$ - to dm-scale mudstone clasts which, on thin section, can be unambiguously recognized as representing rip-ups eroded from the hemipelagic marlstones below $\mathrm{CdV}$ based on similar composition (see below) and micropaleontological content. The texture is grain-supported with variable amount (from absent to $8 \%$ ) of mixed clay-carbonate matrix, which is most commonly found in those samples collected close to bed bases and marlstone rip-up clasts.

Detrital grains are dominated by lithic fragments from metamorphic rocks (orthogneisses with muscovite and garnet or epidote, micaschists, schists with glaucophane and chloritoid, phyllites) and serpentinites (Figure 11a-f). Other rare to sparse lithic fragments include volcanic rocks, chert fragments, shales, crystalline carbonates, probably marbles (Figure 11c), and marly wackestone/mudstone rip-up clasts. 

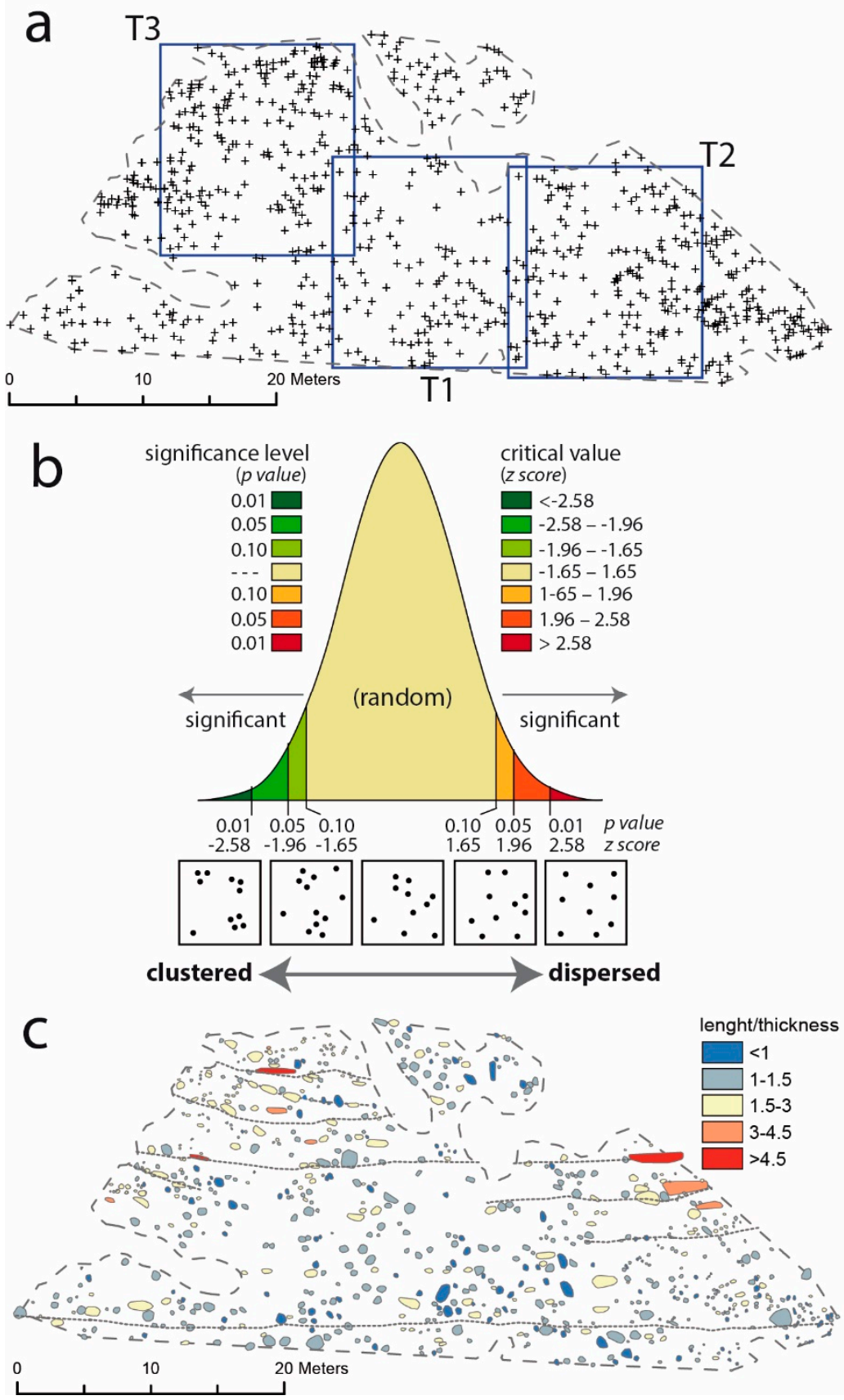

Figure 10. (a) Centroids of concretions from the near vertical face of the studied outcrop (see Figure 3d for location) with test areas (T1-T3) used for computing Average Nearest Neighbour Statistics reported in Table 2; (b) Explanation of z-scores (standard deviation), p-values (probability) and associated significance level thresholds for the normal standard distribution of a random process; (c) Concretion boundaries classified by their $w / t$ ratio. Note how larger and more elongated concretions appear clustered spatially being aligned along bedding (dashed lines). 

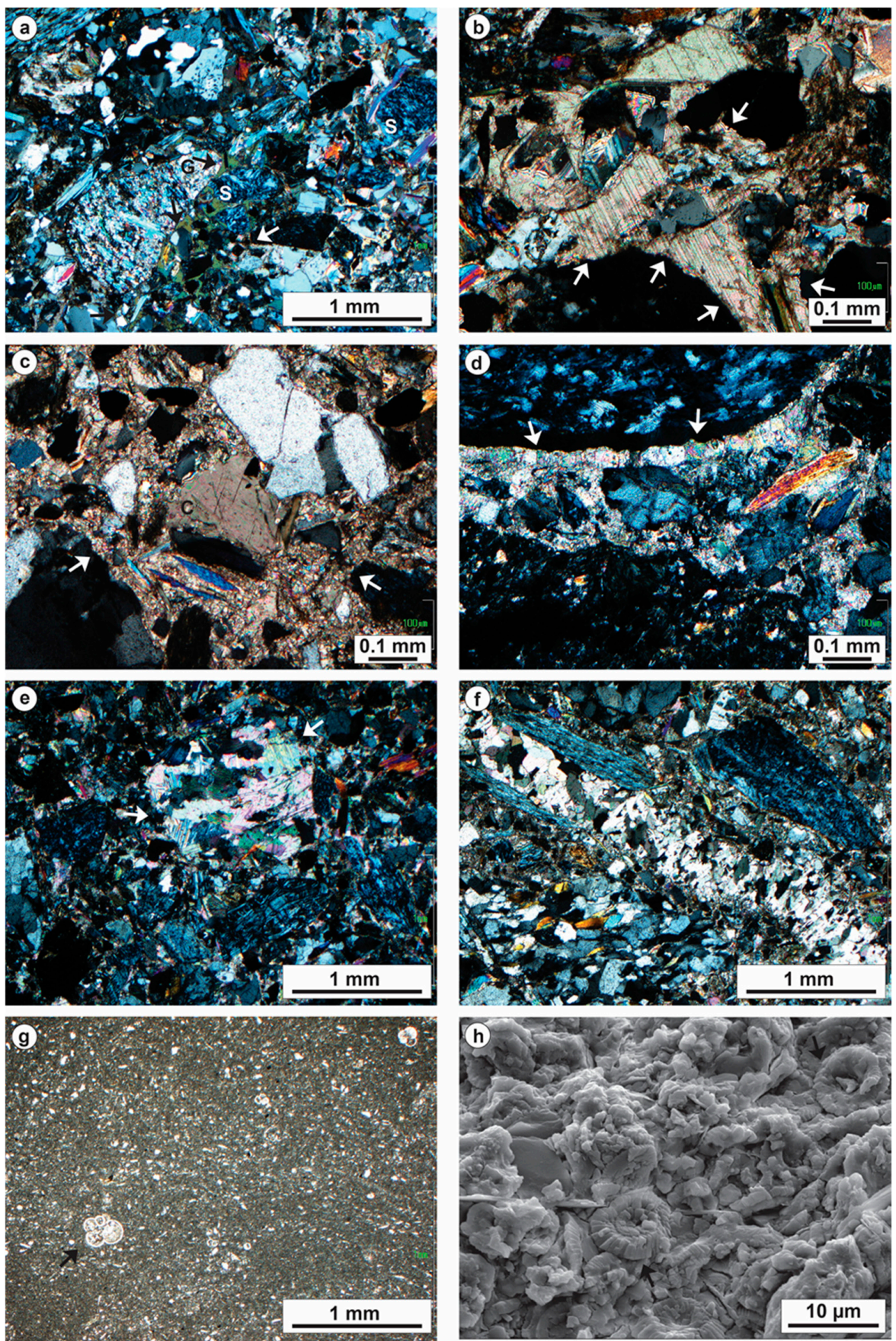

Figure 11. (a) Crossed polarizers photomicrograph of concretions with poikilotopic calcite cement (large crystal embedding several detrital grains, black arrows), gneiss rock fragments (G), muscovite, serpentinite (S) and planktonic foraminifer (white arrow); (b) close-up view of poikilotopic calcite cement (white arrows) embedding various detrital grains including quartz, feldspar and crystalline carbonate; (c) blocky sparite to microsparite cement (white arrows) probably related to carbonate matrix recrystallization embedding quartz, muscovite and crystalline carbonate rock fragments, probably marble (C); (d) blocky equant sparite cement lining serpentinite fragments (white arrows) and filling the interparticle space; e) detrital grain replaced by a mosaic of equant calcite (white arrows) in concretions; (f) Concretion with serpentinite and orthogneiss rock fragments cut by a fracture filled by prismatic and equant sparite; (g) Wackestone/mudstone clast deriving from the hemipelagites below $\mathrm{CdV}$ with planktonic foraminifers (black arrow); (h) SEM image of the hemipelagic marlstones below $\mathrm{CdV}$ showing calcareous nannoplankton coccoliths (black arrows). 
Mineral detrital grains include common to rare quartz, both mono- and polycrystalline, plagioclase, orthoclase, microcline and micas (muscovite, chlorite and rare biotite). Identified accessory minerals are zircon, epidote, garnet, titanite, rutile, glaucophane and magnetite. The rare skeletal fragments are represented by bivalves and benthic (rotalids, miliolids) and planktonic foraminifers.

The marlstones forming the rip-ups and the beds below and above $\mathrm{CdV}$ are mudstone/wackestone with planktonic and buliminid and textularid benthic foraminifers, and sparse bivalve fragments, associated with authigenic framboidal pyrite, silt-grade quartz, plagioclase and mica fragments. These components float in a matrix made of abundant calcareous nannoplankton fragments (coccoliths; Figure $11 \mathrm{~g}, \mathrm{~h}$ ) and chlorite, illite, muscovite, smectite and serpentine as suggested by XRD.

\subsection{Diagenetic Features}

The CdV sandstones show evidences of mechanical compaction such as parallel oriented grains, detrital grain breakage and deformation, elongated to concavo-convex and rarely sutured grain contacts (Figures 11a-f and 12a-d).

Within concretions, the calcite cement constitutes on average ca. $22 \%$ of the analysed thin section area (Figure 13) and there is no petrographically visible porosity (Figure 11a,b and Figure 12a,b).

The most common cement fabric is poikilotopic calcite ( $100 \mu \mathrm{m}$ to $2 \mathrm{~mm}$ in diameter) embedding two to several detrital grains. These include crystalline carbonate rock fragments, which typically lack syntaxial overgrowth of calcite cement (Figure 11a-c).

In samples collected close to bed bases and marlstone rip-ups, the poikilotopic calcite cement is absent to sparse (Figure 11c,d), whereas blocky mosaics of equant sparite (50-200 $\mu \mathrm{m}$ crystal size) to microsparite (20-40 $\mu \mathrm{m}$ crystal size) represent the dominant cement types. These form a non-isopachous calcite cement that lines the grains discontinuously (Figure 11d) and are best interpreted as the product of recrystallization of a carbonate micrite matrix, most likely incorporated by turbidity currents from the hemipelagic marlstones below CdV.

Calcite crystals can also replace some detrital rock fragments and feldspars, developing mosaics of equant sparite (Figure 11e). Cathodoluminescence shows that the poikilotopic calcite cements are uniformly bright orange luminescent, suggesting one single growth phase (Figure 12a-c). Replacive calcite on detrital grains and detrital crystalline carbonate rock fragments appear instead dull, quenched with respect to the poikilotopic calcite cement (Figure 12b). Where the interparticle space is filled by microsparite, this appears dull and quenched with respect to bright luminescent sparite cements.

Fractures are filled by limpid prismatic and equant calcite (Figure 11f) and cut through grain contacts and calcite cements, suggesting their formation and infill postdate mechanical compaction and calcite cementation. Similarly to the interparticle sparite cement, fracture calcite fillings show bright luminescence evolving into quenched dull luminescence.

Samples from the host sandstones display interparticle and vuggy porosity ranging from $8 \%$ to $18 \%$ (with an average value of ca. $15 \%$; Figures $12 \mathrm{~d}-\mathrm{f}$ and 13 ) and detrital clay matrix from 0 to $8 \%$ of the thin section area (Figure 12d-f). It is worth noting that the average porosity of the host sandstones is ca. $7 \%$ less than the pore space filled in by cements in concretions (Figure 13), suggesting the former are comparatively more compacted. 

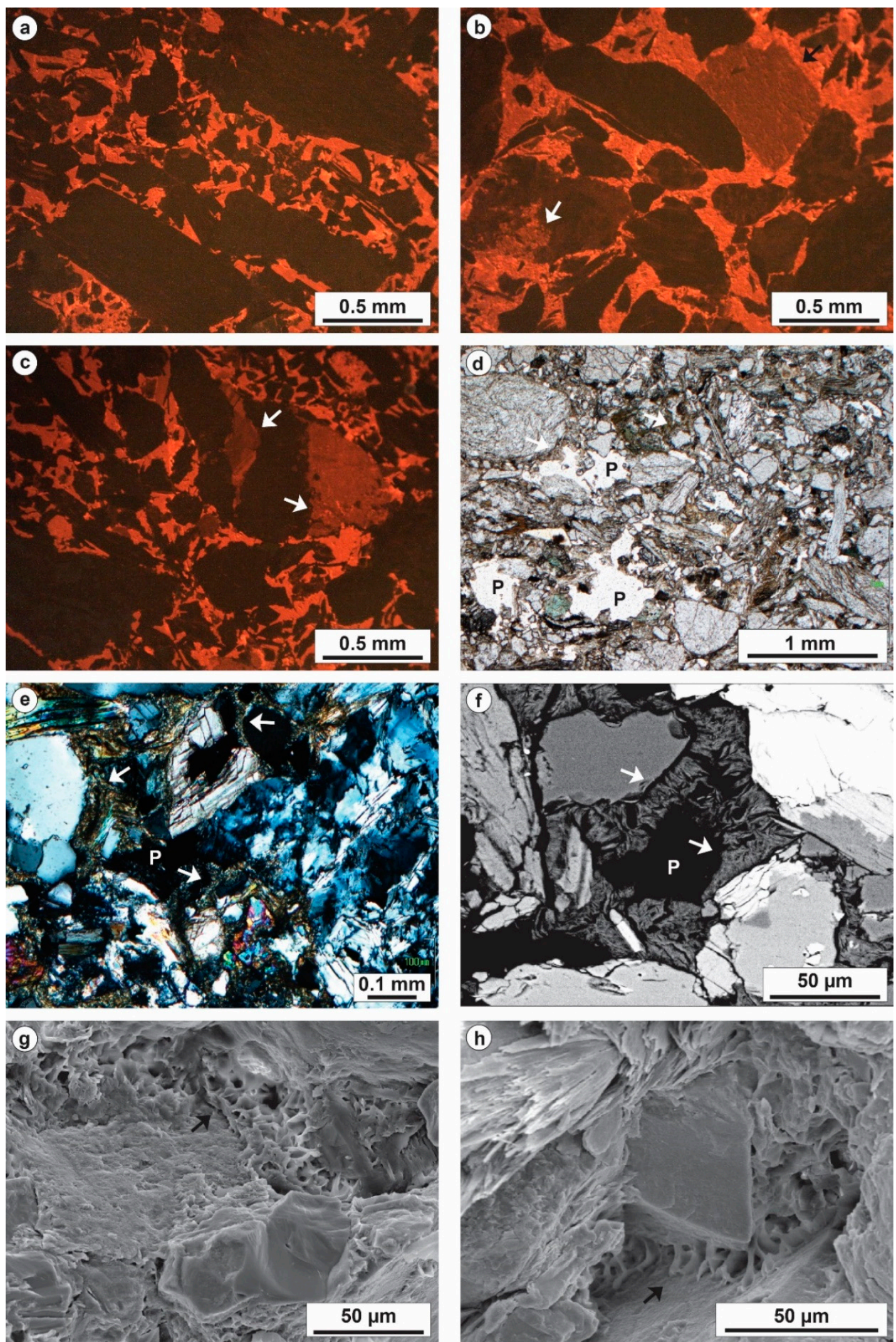

Figure 12. (a) Cathodoluminescence (CL) photomicrograph showing that the poikilotopic calcite cement is uniformly bright orange luminescent and it follows mechanical compaction; (b) CL image showing bright luminescent poikilotopic calcite cement, dull detrital crystalline carbonate grain (black 
arrow) and dull calcite partially replacing a detrital grain (white arrow). Grain contacts are elongated confirming cementation after mechanical compaction; (c) CL photomicrograph showing that the calcite crystals partially replacing a detrital grain are dull, quenched with respect to the bright orange luminescent poikilotopic calcite cement (white arrows); (d) Parallel polarizer image of host sandstone lacking calcite cement and showing interparticle and vuggy porosity $(\mathrm{P})$ and clay matrix around grains (white arrow); (e) Photomicrograph in crossed polarizers of host sandstone showing interparticle porosity $(\mathrm{P})$ and detrital grains surrounded by a brownish rim of clay minerals (white arrows); (f) SEM image of host sandstone thin section showing interparticle pore $(\mathrm{P})$ lined by authigenic fibrous clay mineral cementing the sandstone and growing perpendicular to detrital grains (white arrows); (g) SEM image of freshly broken surface of host sandstone showing an authigenic clay mineral with alveolar texture, likely smectite, cementing the grains (black arrow); (h) SEM image of freshly broken surface of host sandstone showing the authigenic clay mineral forming bridges binding the detrital grains (black arrow).

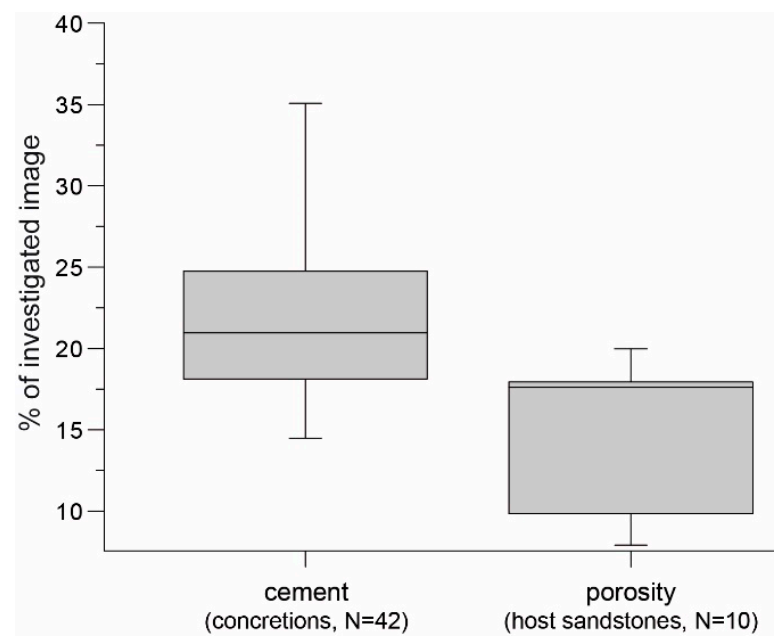

Figure 13. Box-plots of percentages of calcite cements in concretions (left) and preserved porosity in host sandstones (right) estimated from image analysis of cathodoluminescence photomicrographs (concretions) and optical microscopy and SEM photomicrographs (host sandstones).

Most of the detrital grains in the host sandstones appear coated by a 10-50 $\mu$ m-thick clay mineral rim bridging the grains (Figure 12e-h). These clay coatings are ubiquitous in the host sandstones, whereas they seem to be rare to absent in concretions, where the rare clay coatings appear to precede the mechanical compaction and calcite cement precipitation. EDS analyses of these clay mineral coatings indicate a variable composition including $\mathrm{Na}, \mathrm{Ca}, \mathrm{Al}, \mathrm{Si}, \mathrm{Mg}$, Fe.

$\mathrm{XRD}$ analyses of oriented slides made from the $<2 \mu \mathrm{m}$ fraction of the host sandstone powder, performed before and after treatment with glycolate, show the presence of expandable clay minerals, such as smectite, associated with microcline, serpentine, illite and chlorite. The authigenic clay coatings with an alveolar fabric (Figure 12g-h) might be either a smectite or mixed layer smectite-chlorite cement. This hypothesis is supported the synchrotron analyses on thin sections that indicate the presence of smectites, chlorite and muscovite.

\subsection{Stable $\mathrm{C}$ and $\mathrm{O}$ Isotopes}

The results of the carbon and oxygen stable isotope measurements are listed in Table 3 and graphed in Figure 14. It is assumed that the measured $\delta^{13} \mathrm{C}$ and $\delta^{18} \mathrm{O}$ of the $\mathrm{CdV}$ concretions largely reflect the isotopic composition of the calcite cement, whereas the $\delta^{13} \mathrm{C}$ and $\delta^{18} \mathrm{O}$ values of the host sandstones lacking calcite cement chiefly mirror the isotopic signature of the crystalline carbonate lithic fragments. The 21 concretion measurements show $\delta^{18} \mathrm{O}$ mostly between -5.8 and $-8.5 \%$ oxcept for 4 samples with $\delta^{18} \mathrm{O}$ between -10.5 and $-13.3 \%$ (more similar to the host sandstones). 
Table 3. Results of stable carbon and oxygen isotope measurements made on powders extracted from the concretions, the host sandstones and the marlstones rip-ups of $\mathrm{CdV}$, and the hemipelagic marlstones below and above CdV.

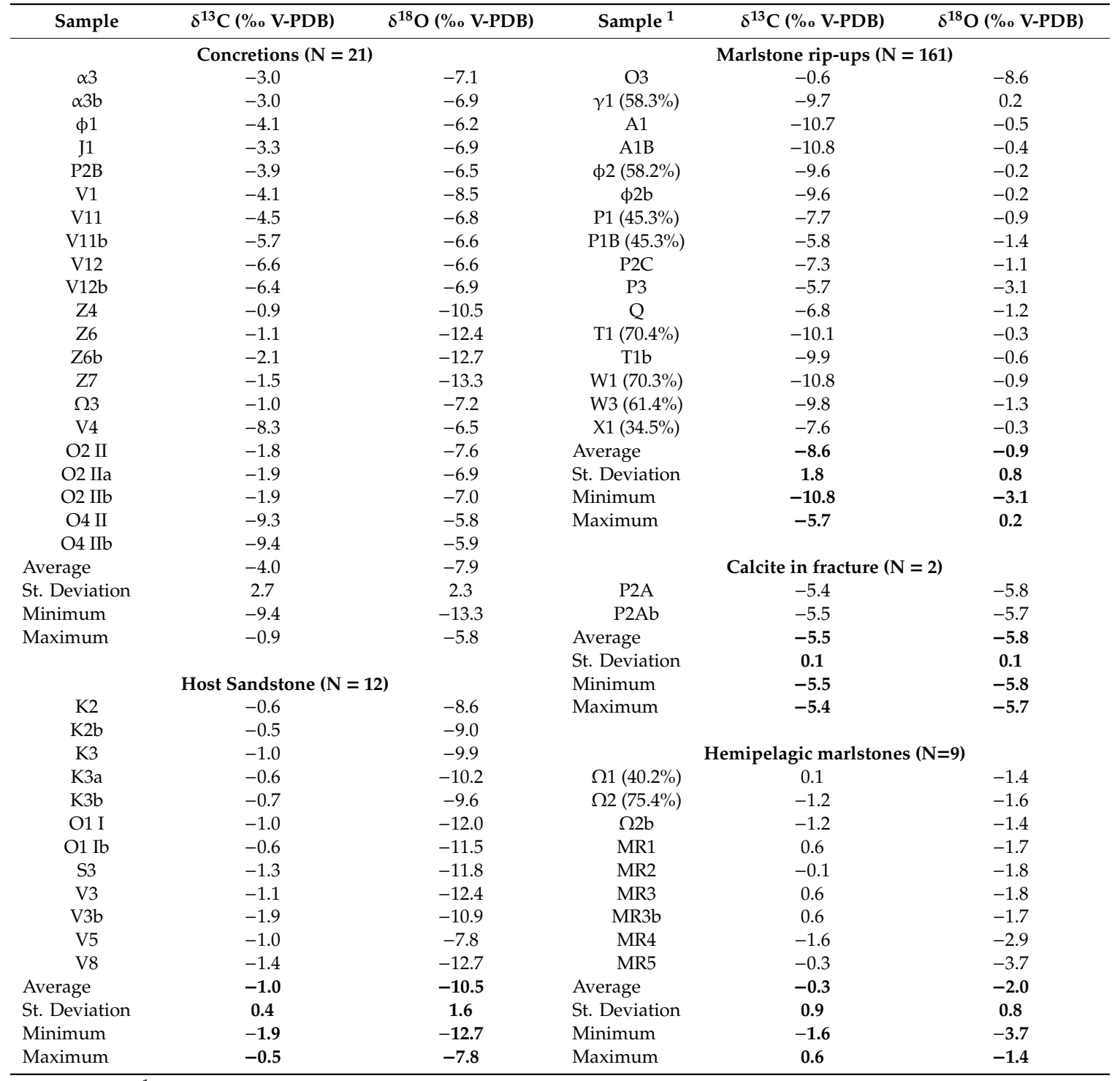

${ }^{1}$ Values reported in brackets are weight percent of carbonate from calcimetry (see Figure 3c).

The concretion $\delta^{13} \mathrm{C}$ values vary from -0.9 to $-9.4 \%$. The stable isotopic signature of one single sample of calcite cement infilling a fracture $\left(\delta^{18} \mathrm{O}-5.8 \%\right.$; $\delta^{13} \mathrm{C}-5.5 \%$ ) is close to the average values from concretions $\left(\delta^{18} \mathrm{O}-4.0 \%\right.$; $\delta^{13} \mathrm{C}-7.9 \%$ ).

Conversely, the host sandstones show $\delta^{18} \mathrm{O}$ values ranging from $-7.8 \%$ o to $-12.7 \%$ o (average $-10.5 \%$ o) and $\delta^{13} \mathrm{C}$ between -0.5 and $-1.9 \%$. It is assumed that this isotopic signature with fairly uniform $\delta^{13} \mathrm{C}$ values with an average of $-1.0 \%$ and variable, highly ${ }^{18} \mathrm{O}$ depleted $\delta^{18} \mathrm{O}$ values, is characteristic of the detrital crystalline carbonate rock fragments, probably marbles.

The hemipelagic marlstones below and above $\mathrm{CdV}$ plot in a different field with heavier average $\delta^{18} \mathrm{O}$ and $\delta^{13} \mathrm{C}$ values of $-2.0 \%$ o (standard deviation sd 0.8 ) and $-0.3 \%$ (sd 0.9 ), respectively. The mudstone rip-up clasts found within the $\mathrm{CdV}$ show $\delta^{18} \mathrm{O}$ values similar to the hemipelagic marlstones (average $\delta^{18} \mathrm{O}-0.9 \%$, sd 0.8 ) and highly ${ }^{13} \mathrm{C}$ depleted values with $\delta^{13} \mathrm{C}$ ranging between -5.7 and $-10.8 \%$. 


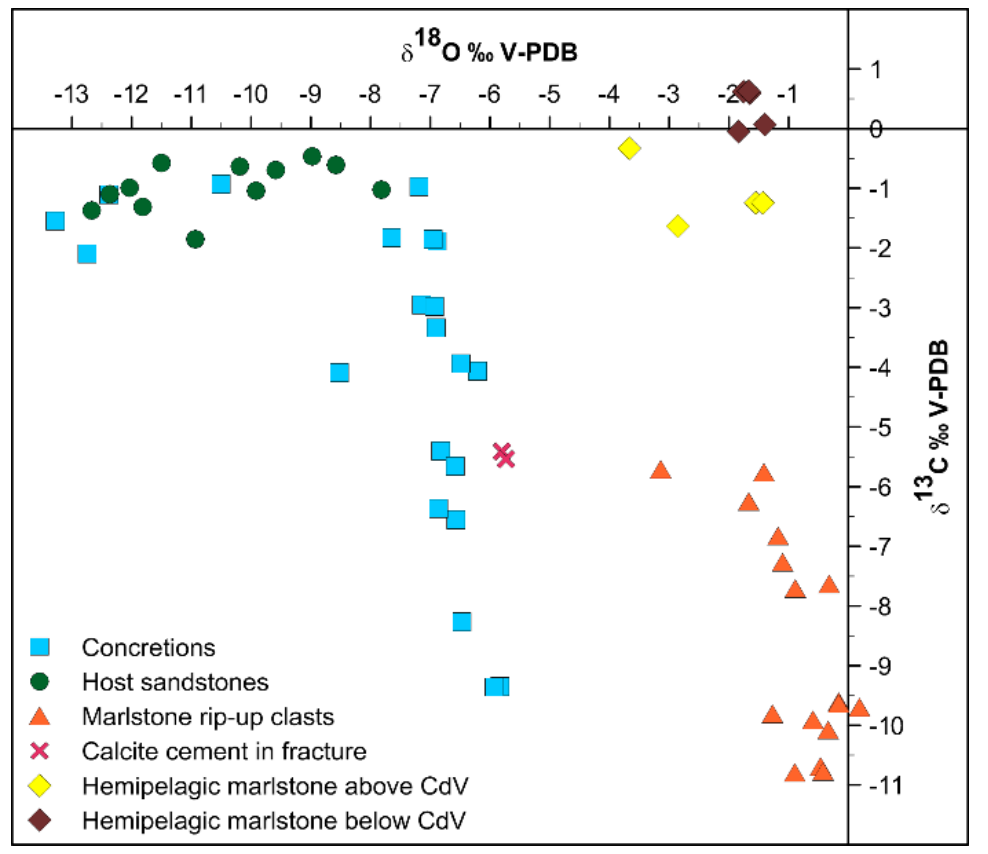

Figure 14. Scatter plot of $\delta^{13} \mathrm{C}$ and $\delta^{18} \mathrm{O}$ measured values from the $\mathrm{CdV}$ concretions and host sandstones, fracture filling calcite, marlstone rip-up clasts and the hemipelagic marlstone underlying and overlying the $\mathrm{CdV}$. The $\mathrm{C}$ and $\mathrm{O}$ stable isotopes of the concretions are interpreted to reflect the $\delta^{13} \mathrm{C}$ and $\delta^{18} \mathrm{O}$ of the calcite cement, whereas that of the host sandstones mirror the $\delta^{13} \mathrm{C}$ and $\delta^{18} \mathrm{O}$ of carbonate lithic fragments, because they represent the only carbonate component present in the host sandstones. $\mathrm{C}$ and $\mathrm{O}$ stable isotopes support the interpretation that the calcite cement precipitated during burial diagenesis with the carbonate ions deriving from the alteration and dissolution of the hemipelagic marlstone rip-up clasts embedded within the sandstones.

\subsection{Diagenesis Interpretation}

Authigenic clay mineral coatings, determined as smectite or less likely mixed smectite-chlorite layers (see Section 3.4), are ubiquitously present in both host sandstones and concretions also along grain contacts. This suggests that they might have formed during the eodiagenesis before burial mechanical compaction and calcite cementation (as reported for authigenic trioctahedral smectites in sediments with volcanic fragments and mafic minerals; [3,7,55]), likely playing a key role in preventing the syntaxial growth of cements around detrital grains [7] and preserving the observed interparticle porosity of the host sandstones, which can be as high as $18 \%$. In addition, the presence of authigenic smectites implies that, during burial, temperature remained sufficiently low $\left(<70{ }^{\circ} \mathrm{C} ;\right)$ to prevent complete transformation into chlorite or illite $[5,55]$, which is in agreement with the maximum burial depth and temperature (i.e., $1250-1550 \mathrm{~m}$ and $30-36^{\circ} \mathrm{C}$, respectively) proposed by Milliken et al. [44].

Calcite cementation in the concretions is interpreted as a burial diagenetic process following mechanical compaction as confirmed by the poikilotopic fabric and the bright luminescence of the calcite cement, indicative of reducing conditions favoring incorporation of $\mathrm{Mn}^{2+}$ within calcite crystals [56-59]. Though indicated as absent by previous authors $[1,24,44]$, the bright luminescent poikilotopic cement stands out as the dominant cement type, thus providing an additional evidence for concretion forming at or near maximum burial depth.

Grain replacement by calcite was probably time-equivalent to calcite cementation and/or a following process as suggested by the dull quenched luminescence indicative of stronger reducing conditions due to $\mathrm{Fe}^{2+}$ incorporation in the calcite crystals [56,59]. Cross-cutting relationships suggest fracture formation and filling by sparite followed mechanical compaction and calcite cementation.

It should be observed that, regardless of the cement type, in calcite cements completely occlude the interparticle space of concretions, representing on average ca. $22 \%$ of the analysed thin section 
area. Such values are higher than the average porosity of the host sandstones (ca. 15\%, Figure 12) supporting the idea that concretion formation occurred slightly before maximum burial $[24,44]$ and that compaction of the host sandstones continued after calcite cementation.

The marlstones below and above $\mathrm{CdV}$ show $\delta^{13} \mathrm{C}$ and $\delta^{18} \mathrm{O}$ close to Oligocene marine values [60] suggestive of a nearly $\delta^{13} \mathrm{C}$ pristine isotopic signature and $\delta^{18} \mathrm{O}$ values depleted in ${ }^{18} \mathrm{O}$ by up to ca. $4 \%$, whereas the rip-ups display strongly negative $\delta^{13} \mathrm{C}$ values and $\delta^{18} \mathrm{O}$ in a similar range as the marlstones. This stable isotope data point to the marlstones rip-ups found at the core of concretions as the local source of dissolved inorganic carbon (DIC) for calcite cement precipitation: in fact, though unambiguously identifiable as eroded from the marlstones below $\mathrm{CdV}$, the rip-ups are depleted in ${ }^{13} \mathrm{C}$ with respect to the marlstones, with $\delta^{13} \mathrm{C}$ in the same range as the calcite cement in the concretions. This suggests leaching of rip-ups by a ${ }^{12} \mathrm{C}$-rich fluid, diffusion in the surrounding sands and precipitation of concretion-forming calcite.

The ${ }^{12} \mathrm{C}$-rich fluid vehiculating carbonate ions by diffusion could have been either a deeply circulated meteoric water or a connate fluid or a combination thereof, whose negative $\delta^{13} \mathrm{C}$ would reflect a contribution of ${ }^{12} \mathrm{C}$ from organic matter contained in soils or sediments, respectively [44,57,61-63].

The $\delta^{18} \mathrm{O}$ values of the concretions, highly ${ }^{18} \mathrm{O}$-depleted with respect to both the rip-ups and the marlstones below and above $\mathrm{CdV}$, might be interpreted to reflect calcite precipitation at relatively higher temperatures close to maximum burial [44,61-63].

Yet, the range of $\delta^{18} \mathrm{O}$ of concretions slightly overlap that of the host sandstones, which typically show more ${ }^{18} \mathrm{O}$-depleted $\delta^{18} \mathrm{O}$ values common to crystalline carbonate lithic fragments (most likely marbles) recrystallized at high temperatures. Such overlap finds explanation in the impracticality of selectively targeting the cement of concretion samples with the drill when preparing powders to be analysed, which might have resulted in unwanted contamination from framework grains.

These results fit well the model proposed by Milliken et al. [44] which explains stable C and O isotope data of the concretions of $\mathrm{CdV}$ and similar case studies from the Apennine wedge-top with local dissolution of the carbonate (bioclasts and marlstone rips- ups) by deeply-circulated meteoric waters from nearby thrust-belt mountains. In this model, mixing with residual seawater, together with rock-water interaction processes, might have contribute additional ${ }^{18} \mathrm{O}$ to the meteoric fluid dissolving ions from the marlstones, explaining the observed $\delta^{18} \mathrm{O}$ values. The negative $\delta 13 \mathrm{C}$ would reflect oxidation or thermal degradation of organic matter [44].

\section{Discussion}

\subsection{Likely Sedimentary Controls on Concretion Development}

$\mathrm{CdV}$ concretions have been found to be spatially associated with a carbonate-rich mud-grade component occurring in different forms within different facies (marlstone rip-up, recrystallized detrital micrite matrix, mud-caps), as a result of the ability of parent flow to entrain mud from the substrate and redeposit it within the channel-fill. Carbon and Oxygen stable isotope data identify this carbonate-rich component as the major source of $\mathrm{CaCO}_{3}$ : the marlstone rip-ups and the associated calcite-cemented concretions appear in fact both depleted in ${ }^{13} \mathrm{C}$ and ${ }^{18} \mathrm{O}$ in comparison to the marlstones above and below $\mathrm{CdV}$, suggesting that the carbonate ions were locally brought into solution by a ${ }^{12} \mathrm{C}$ - and ${ }^{16} \mathrm{O}$-rich fluid originated from mixing of deeply circulated meteoric water and a connate fluid (see e.g., [44]), precipitating the concretion-cementing calcite at relatively higher temperatures near to maximum burial.

Differently from what is reported for similar deposits [2,14], where the sandstone channel-fill is continuously surrounded by a massively cemented rim at the contact with the embedding mudstones, only the base of CdV is massively cemented, whereas CDV top shows a patchy cementation. This suggests that diffusion from a common source of carbonate (i.e., the marlstone above and below $\mathrm{CdV}$ ) alone cannot explain the diverse cementation pattern of $\mathrm{CdV}$ base and top, and that other controls should be invoked. One possibility is that the massive calcite cementation of the lowermost CdV 
might reflect two main superimposed factors, namely an expectedly higher permeability of the deposit, favorable to carbonate diffusion from the marlstone below, and a higher volumetric proportion of marlstone rip-ups, which provided additional amount of carbonate ions. Oppositely, the uneven cementation of the CdV top would suggest the low permeability of the fine-grained cross-laminated facies prevented extensive diffusion of carbonate ions from the marlstone above but rather focused it along high-permeability pathways $[10,15]$ resulting in development of discrete concretions.

Despite the high-resolution of the photogrammetric outcrop model used in this investigation, distinguishing and extensively mapping sandstone textures was not undertaken because prone to much subjectivity. Though this prevented demonstrating quantitatively the relationship between the uneven calcite cementation and facies, the results presented in Sections 3.2 and 3.3 show that a correlation between concretion characteristics and the facies architecture exists. In fact, while, equant concretions are ubiquitous and homogeneously dispersed within $\mathrm{CdV}$, the larger highly elongated concretions become more abundant up-section and off the channel axis where they tend to cluster along bedding, associated with a more layered architecture with locally preserved mud caps and higher proportions of finer-grained, better sorted facies.

As noted by McBride et al. [1], larger equant concretions appear to systematically develop around marlstone rip-ups, most frequently in the coarser-grained, rip-up clasts-rich, lower half of turbidite beds, whereas smaller ones are found almost exclusively in finer-grained laminated tops, seemingly neither associated with marlstone rip-ups nor in contact with an overlying mud cap. Conversely, sub-equant to highly elongated concretions are located preferentially at the base of beds, either overlying preserved mud caps or straddling amalgamation surfaces not associated with either marlstone rips ups or mud cap remnants. There are thus examples of both concretion shape end-members that lack an obvious local source of carbonate ions but are still cemented by calcite. This observation can be explained by the presence of the blocky sparite and microsparite cements in some thin sections, interpretable as the product of recrystallization of a carbonate-rich micrite matrix. This detrital micrite matrix was likely present in various proportions in different facies and acted as a more 'dispersed' source of carbonate.

These findings highlights that the processes by which mud was eroded from the channel substrate and deposited are key in controlling where and in which form the carbonate-rich component is trapped within the sandstone fill of turbidite channels entrenched into older marly deposits.

\subsection{Prediction and Likely Impact on Reservoir Properties}

The results of this study allow envisaging a reference framework or model for heterogeneous calcite cementation of turbidite channel-fills, useful for predicting location of tightly cemented non-reservoir zones in subsurface analogues hosting hydrocarbons $[2,6,14]$. This is underpinned on the observation that shape and size of concretions, as well as their volume fraction changes systematically with CdV (Sections 3.2 and 3.3) reflecting the type and spatial patter of local source of carbonate ion available for diffusion in the surrounding deposit.

The model would entail an early stage of channel inception and by-pass in which highly erosive flows cut into the underlying marlstone and fill in the channel with a coarse-grained lag charged with large-size rip-ups. This early stage results in a tightly cemented lower interval where the marlstone below and the abundant rip-ups provides carbonate ions to circulating burial diagenetic fluids. In CdV, such a tightly cemented non-reservoir zone is lens-shaped and up to 5 metres-thick in the channel axis, representing less than ca. $20 \%$ of the channel-fill cross sectional area.

Above this non-reservoir zone, the model involves a package of amalgamated sandstones with scoured bases and abundant marlstone rips-up clasts, fringing toward channel margins as result of an increased preservation of mud caps (cf. with bed sets I-II in Figure 3a). This sedimentary package reflects deposition by high-density flows capable of eroding both large rip-ups from consolidated mudstones and mud-grade particles from unconsolidated hemipelagites and channel-drapes, which are segregated in the turbulent cloud and redeposited as carbonate-rich mud caps. Though sedimentary facies from this interval might yield relatively high porosity, equant to sub-equant concretions developed 
around marlstone rip-ups can represent an average volume fraction of up to ca. $20 \%$. However, the arrangement and lateral continuity of these concretions, together with an expectedly high permeability of the uncemented host, should not represent a major issue for connectivity. Yet, the increased fraction of elongated concretions developed adjacent to preserved mud caps may result in a reduction of volume reservoir facies as well as a more layered permeability structure toward channel margins.

The late fill stage of the model appears the most critical by a reservoir perspective, both for the lower permeability of dominant sedimentary facies and a greater average volume and lateral continuity of concretions. Since the erosive ability of the flows transiting the channel is progressively decreasing over time, at this stage the carbonate-rich component is chiefly entrained from the unconsolidated substrate as detrital micrite and trapped in the channel-fill in form of either mud caps or matrix filling the interparticle pore-space of sandstones. During burial diagenesis, carbonate ions diffusion from mud caps and recrystallization of matrix micrite are thought to have both contributed to formation of highly elongated, strata-bound concretions and completely cemented beds (bed sets III-IV). As a result, the late-stage fill channels developed on marly substrates would be comparatively more prone to highly tortuous flow pathways or even compartmentalized due to calcite cementation.

The above model provides probabilistic constraints on spatial distribution of calcite-cemented concretions which can be used, in combination with sedimentary facies, to inform fine-scale geostatistical modelling of poro-permebility properties of hydrocarbon reservoirs hosted in turbidite channel-fill [2,6,14,25,64].

It must be noted that because the underlying concept of this contribution is linking heterogeneous calcite cementation to processes by which the carbonate component is trapped within the channel-fill, the proposed model can be applied to other type of turbidite channel-fills after modifications accounting for different parent flows and sedimentary facies [51,52]. Once defined the lower hierarchy building block of the analogue reservoir, after adaptation the proposed reference model is usable at a range of hierarchical scales, from single-story channels to submarine fan conduit complexes [65].

In conclusion, it is suggested that the discrete nature of concretions makes an object-based approach [66] the best suited technique for stochastically modelling heterogeneous calcite cementation, in which insertion of objects with different shapes and size can be conditioned to statistics from outcrop analogues similar to CdV.

\section{Conclusions}

The shape, size and spatial distribution of calcite concretions developed within the sand-prone fill of a turbidite incisional channel entrenched into hemipelagic marlstones were evaluated using UAV photogrammetry of a well-exposed outcrop. The controls on heterogeneous cementation were addressed with the combined use of facies, petrography and carbon and oxygen stable isotope analyses. Results are as follows:

- The channel-fill comprises a lower tightly cemented conglomeratic sandstone charged with large rip-ups eroded from the marlstone below, replaced up-section by amalgamated turbidite sandstone

- Turbidites are locally rich in marlstone rip-ups and become progressively finer grained, more laminated and less amalgamated up-section and off the channel axis

- Concretions show a range of equant to oblate shapes with their long axes laying in the bedding plane and volumes ranging from ca. $3^{*} 10^{-4}$ to $3 \mathrm{~m}^{3}$

- Equant concretions are ubiquitous and often associated with marlstone rip-ups

- Oblate concretions include highly elongated, strata-bound concretions and completely cemented beds developed above preserved mud caps or straddling surfaces of bed amalgamation

- Up-section and off the channel axis the proportion of elongated concretions increases

- Calcite cement precipitated near to maximum burial depth 
- Carbon and oxygen stable isotope data suggest that the marlstone material eroded from the channel substrate and trapped within the channel-fill in different forms (rip-ups, matrix micrite and mud caps) represents the source of carbonate ions for calcite cementation

- The concretion pattern of the studied channel-fill is typified by a tightly cemented lower zone, an intermediate unevenly cemented zone where oblate concretions are dominant and homogenously dispersed, and an upper zone with highly elongated concretions whose lateral continuity can exceed the size of the outcrop

- The results of this contribution find application in prediction and geostatistical modelling of heterogeneous calcite cementation of analogue hydrocarbon reservoirs at a range of scales

Author Contributions: Conceptualization, M.M., G.D.P. and F.F.; methodology, M.M., G.D.P., M.F., and V.C.; software, M.M., B.M.G., M.F., and V.C.; validation, M.M., G.D.P., M.F., and V.C.; formal analysis, M.M., G.D.P. and B.M.G.; investigation, M.M. and G.D.P.; resources, M.M., G.D.P. and F.F.; data curation, M.M., G.D.P. and M.F.; writing—original draft preparation, M.M. and G.D.P.; writing—review and editing, M.M., G.D.P., F.F., M.F.; visualization, M.M.; supervision, M.M. and F.F.; project administration, M.M., G.D.P. and F.F.

Funding: This research received no external funding.

Acknowledgments: We are also grateful to Schlumberger ${ }^{\mathrm{TM}}$ which has supplied an academic license of Petrel $2017^{\mathrm{TM}}$ to the Earth Sciences Department 'Ardito Desio' of the University of Milan. David Hodgetts (University of Manchester) is thanked for access to Virtual Reality Geological Studio (VRGS) software for 3D data visualisation and interpretation (C) 2017. VRGeoscience). Stefano Maggio is thanked for contributing to the fieldwork and interpretation of the digital outcrop model made in VRGS. The authors warmly thank the several colleagues from the Earth Sciences Department of the University of Milan who contributed to sample preparation and laboratory analyses: Marco Merlini for the synchrotron mineralogy analysis, Monica Dapiaggi for XRD measurements, Elena Ferrari for stable isotope analyses, Curzio Malinverno for thin section preparation, Chiara Compostella for calcimetry analyses, and Agostino Rizzi for assistance at the SEM.

Conflicts of Interest: The authors declare no conflict of interest.

\section{References}

1. McBride, E.F.; Milliken, K.L.; Cavazza, W.; Cibin, U.; Fontana, D.; Picard, M.D.; Zuffa, G.G. Heterogeneous distribution of calcite cement at the outcrop Scale in Tertiary Sandstones, Northern Apennines, Italy. Am. Assoc. Pet. Geol. Bull. 1995, 79, 1044-1062. [CrossRef]

2. Carvalho, M.V.; De Ros, L.F.; Gomes, N.S. Carbonate cementation patterns and diagenetic reservoir facies in the Campos Basin Cretaceous Turbidites, Offshore Eastern Brazil. Mar. Pet. Geol. 1995, 12, 741-758. [CrossRef]

3. Morad, S. Carbonate cementation in sandstones: Distribution patterns and geochemical evolution. In Carbonate Cementation in Sandstones; Morad, S., Ed.; International Association of Sedimentologists Special Publication: Cambridge, UK, 1998; Volume 26, pp. 53-85. [CrossRef]

4. Morad, S.; De Ros, L.F.; Nystuen, J.P.; Bergan, M. Carbonate diagenesis and porosity evolution in sheet-flood sandstones: Evidence from the Middle and Lower Lunde Members (Triassic) in the Snorre Field, Norwegian North Sea. In Carbonate Cementation in Sandstones; Morad, S., Ed.; International Association of Sedimentologists Special Publication: Cambridge, UK, 1998; Volume 26, pp. 53-86. [CrossRef]

5. Worden, R.H.; Burley, S.D. Sandstone diagenesis: The evolution of sand to stone. In Sandstone Diagenesis: Recent and Ancient; Burley, S.D., Worden, R.H., Eds.; Reprint Series; International Association of Sedimentologists Special Publication: Oxford, UK, 2003; Volume 4, pp. 3-44. [CrossRef]

6. Dutton, S.P.; Flanders, W.A. Evidence of Reservoir Compartmentalization by Calcite Cement Layers in Deepwater Sandstones; Bell Canyon Formation: Delaware Basin, TX, USA; Geological Society: London, UK, 2004; Volume 237, pp. 279-282. [CrossRef]

7. Morad, S.; Al-Ramadan, K.; Ketzer, J.M.; De Ros, L.F. The Impact of diagenesis on the heterogeneity of sandstone reservoirs: A review of the role of depositional facies and sequence stratigraphy. Am. Assoc. Pet. Geol. Bull. 2010, 94, 1267-1309. [CrossRef]

8. Ajdukiewicz, J.M.; Lander, R.H. Sandstone reservoir quality prediction: The state of the art. Am. Assoc. Pet. Geol. Bull. 2010, 94, 1083-1091. [CrossRef] 
9. Hendry, J.P.; Trewin, N.H.; Fallick, A.E. Low-Mg calcite marine cement in Cretaceous turbidites: Origin, spatial distribution and relationship to seawater chemistry. Sedimentology 1996, 43, 877-900. [CrossRef]

10. Mozley, P.S.; Davis, J.M. Relationship between oriented calcite concretions and permeability correlation structure in an alluvial aquifer, Sierra Ladrones Formation, New Mexico. J. Sed. Res. 1996, 66, 11-16.

11. Dutton, S.P.; White, C.D.; Willis, B.J.; Novakovic, D. Calcite cement distribution and its effect on fluid flow in a deltaic sandstone, Frontier Formation, Wyoming. Am. Assoc. Pet. Geol. Bull. 2002, 86, 2007-2021. [CrossRef]

12. Morris, J.E.; Hampson, G.J.; Johnson, H.D. A sequence stratigraphic model for an intensely bioturbated shallow-marine sandstone: The Bridport Sand Formation, Wessex Basin, UK. Sedimentology 2006, 53, 1229-1263. [CrossRef]

13. Lee, K.; Gani, M.R.; McMechan, G.A.; Bhattacharya, J.P.; Nyman, S.L.; Zeng, X. Three-dimensional facies architecture and three-dimensional calcite concretion distributions in a tide-influenced delta front, Wall Creek Member, Frontier Formation, Wyoming. Am. Assoc. Pet. Geol. Bull. 2007, 91, 191-214. [CrossRef]

14. Dutton, S.P. Calcite cement in Permian deep-water sandstones, Delaware Basin, west Texas: Origin, distribution, and effect on reservoir properties. Am. Assoc. Pet. Geol. Bull. 2008, 92, 765-787. [CrossRef]

15. Loope, D.B.; Kettler, R.M.; Weber, K.A. Morphologic clues to the origins of iron oxide-cemented spheroids, boxworks, and pipelike concretions, Navajo Sandstone of south-central Utah, USA. J. Geol. 2011, 119, 505-520. [CrossRef]

16. El-Ghali, M.A.K.; El Khoriby, E.; Mansurbeg, H.; Morad, S.; Ogle, N. Distribution of carbonate cements within depositional facies and sequence stratigraphic framework of shoreface and deltaic arenites, Lower Miocene, the Gulf of Suez rift, Egypt. Mar. Pet. Geol. 2013, 45, 267-280. [CrossRef]

17. Ma, P.; Lin, C.; Zhang, S.; Dong, C.; Zhao, Y.; Dong, D.; Shehzad, K.; Awais, M.; Guo, D.; Mu, X. Diagenetic history and reservoir quality of tight sandstones: A case study from Shiqianfeng sandstones in upper Permian of Dongpu Depression, Bohai Bay Basin, eastern China. Mar. Pet. Geol. 2018, 89, 280-299. [CrossRef]

18. Morad, S. (Ed.) Carbonate Cementation in Sandstones: Distribution Patterns and Geochemical Evolution; John Wiley \& Sons: Hoboken, NJ, USA, 2009; Volume 72. [CrossRef]

19. Bjørlykke, K. Relationships between depositional environments, burial history and rock properties. Some principal aspects of diagenetic process in sedimentary basins. Sed. Geol. 2014, 301, 1-14. [CrossRef]

20. Bjørkum, P.A.; Walderhaug, O. Geometrical arrangement of calcite cementation within shallow marine sandstones. Earth-Sci. Rev. 1990, 29, 145-161. [CrossRef]

21. Spadafora, E.; De Ros, L.F.; Zuffa, G.G.; Morad, S.; Al-Aasm. Diagenetic evolution of synorogenic hybrid and lithic arenites (Miocene), northern Apennines, Italy. In Carbonate Cementation in Sandstones; Morad, S., Ed.; International Association of Sedimentologists Special Publication: Cambridge, UK, 1998; Volume 26, pp. 241-260. [CrossRef]

22. Beitler, B.; Parry, W.T.; Chan, M.A. Fingerprints of fluid flow: Chemical diagenetic history of the Jurassic Navajo Sandstone, southern Utah, USA. J. Sed. Res. 2005, 75, 547-561. [CrossRef]

23. Bjørkum, P.A.; Walderhaug, O. Isotopic composition of a calcite-cemented layer in the Lower Jurassic Bridport Sands, southern England: Implications for formation of laterally extensive calcite-cemented layers. J. Sed. Petrol. 1993, 63, 678-682. [CrossRef]

24. Cibin, U.; Cavazza, W.; Fontana, D.; Milliken, K.L.; McBride, E.F. Comparison of composition and texture of calcite-cemented concretions and host sandstones, Northern Apennines, Italy. J. Sed. Res. 1993, 63, 945-954. [CrossRef]

25. White, C.D.; Novakovic, D.; Dutton, S.P.; Willis, B.J. A geostatistical model for calcite concretions in sandstone. Math. Geol. 2003, 35, 549-575. [CrossRef]

26. Buckley, S.J.; Howell, J.A.; Enge, H.D.; Kurz, T.H. Terrestrial laser scanning in geology: Data acquisition, processing and accuracy considerations. J. Geol. Soc. 2008, 165, 625-638. [CrossRef]

27. Marini, M.; Milli, S.; Rossi, M.; De Tomasi, V.; Meda, M.; Lisi, N. Multi-scale characterization of the Pleistocene-Holocene Tiber delta deposits as a depositional analogue for hydrocarbon reservoirs. J. Mediterr. Earth Sci. Spec. Issue 2013, 103, 109-110.

28. Assali, P.; Grussenmeyer, P.; Villemin, T.; Pollet, N.; Viguier, F. Surveying and modeling of rock discontinuities by terrestrial laser scanning and photogrammetry: Semi-automatic approaches for linear outcrop inspection. J. Struct. Geol. 2014, 66, 102-114. [CrossRef] 
29. Casella, V.; Franzini, M. Modelling steep surfaces by various configurations of nadir and oblique photogrammetry. ISPRS Ann. Photogramm. Remote Sens. Spat. Inf. Sci. 2016, 3. [CrossRef]

30. Chesley, J.T.; Leier, A.L.; White, S.; Torres, R. Using unmanned aerial vehicles and structure-from-motion photogrammetry to characterize sedimentary outcrops: An example from the Morrison Formation, Utah, USA. Sediment. Geol. 2017, 354,1-8. [CrossRef]

31. Nieminski, N.M.; Graham, S.A. Modeling stratigraphic architecture using small unmanned aerial vehicles and photogrammetry: Examples from the Miocene East Coast Basin, New Zealand. J. Sediment. Res. 2017, 87, 126-132. [CrossRef]

32. Madjid, M.Y.A.; Vandeginste, V.; Hampson, G.; Jordan, C.J.; Booth, A.D. Drones in carbonate geology: Opportunities and challenges, and application in diagenetic dolomite geobody mapping. Mar. Petrol. Geol. 2018, 91, 723-734. [CrossRef]

33. Ricci Lucchi, F. The Oligocene to Recent foreland basins of the northern Apennines. In Foreland Basins; Blackwell Scientific: Oxford, UK, 1986; Volume 8, pp. 105-139. [CrossRef]

34. Biella, G.C.; Clari, P.; De Franco, R.; Gelati, R.; Ghibaudo, G.; Gnaccolini, M.; Lanza, R.; Polino, R.; Ricci, B.; Rossi, P.M. Geometrie crostali al nodo Alpi/Appennino: Conseguenze sull'evoluzione cinematica dei bacini neogenici. In Proceedings of the 76 Congresso della Società Geologica Italiana, Firenze, Italy, 20-26 September 1992; pp. 192-195.

35. Maino, M.; Decarlis, A.; Felletti, F.; Seno, S. Tectono-sedimentary evolution of the Tertiary Piedmont Basin (NW Italy) within the Oligo-Miocene central Mediterranean geodynamics. Tectonics 2013, 32, 593-619. [CrossRef]

36. Stocchi, S.; Cavalli, C.; Baruffini, L. The Guaso (south-central Pyrenees), Gremiasco and Castagnola (eastern sector of Tertiary Piedmont basin) turbidite deposits: Geometry and detailed correlation pattern. Atti Ticinensi Scienze della Terra 1992, 35, 153-177.

37. Baruffini, L.; Cavalli, C.; Papani, L. Detailed stratal correlation and stacking patterns of the Gremiasco and lower Castagnola turbidite systems, Tertiary Piedmont Basin, northwestern Italy. In 15th Annual Research Conference Submarine Fans and Turbidite Systems; Weimer, P., Bouma, A.H., Perkins, B.F., Eds.; GCSSEPM Foundation: Houston, TX, USA, 1994; pp. 9-21. [CrossRef]

38. Marini, M.; Patacci, M.; Felletti, F.; McCaffrey, W.D. Fill to spill stratigraphic evolution of a confined turbidite mini-basin succession, and its likely well bore expression: The Castagnola Fm, NW Italy. Mar. Pet. Geol. 2016, 69, 94-111. [CrossRef]

39. Marini, M.; Felletti, F.; Milli, S.; Patacci, M. The thick-bedded tail of turbidite thickness distribution as a proxy for flow confinement: Examples from Tertiary basins of central and northern Apennines (Italy). Sed. Geol. 2016, 341, 96-118. [CrossRef]

40. Cavanna, F.; Di Giulio, A.; Galbiati, B.; Mosna, S.; Perotti, C.R.; Pieri, M. Carta Geologica dell'estremità orientale del Bacino Terziario Ligure-Piemontese. Atti Ticinesi Scienze della Terra 1989, 32.

41. Marroni, M.; Ottria, G.; Pandolfi, L. Note Illustrative della Carta Geologica d'Italia alla scala 1: 50,000 Foglio 196 Cabella Ligure; Istituto Poligrafico e Zecca dello Stato: Roma, Italy, 2010.

42. Di Giulio, A.; Galbiati, B. Escursione nell'estremità orientale del Bacino Terziario Piemontese: Interazione tettonica eustatismo nella sedimentazione di un bacino tardo post-orogenico. 3 Convegno del Gruppo di Sedimentologia del C.N.R. 1993, 1-28.

43. Bellinzona, G.; Boni, A.; Braga, G.; Marchetti, G. Note illustrative della Carta Geologica d'Italia in scala 1: 100,000, Foglio 71, Voghera; Servizio Geologico d'Italia: Roma, Italy, 1971.

44. Milliken, K.L.; McBride, E.F.; Cavazza, W.; Cibin, U.; Fontana, D.; Picard, M.D.; Zuffa, G.G. Geochemical history of calcite precipitation in Tertiary sandstones, northern Apennines, Italy. In Carbonate Cementation in Sandstones; Morad, S., Ed.; International Association of Sedimentologists Special Publication: Cambridge, UK, 1998; Volume 26, pp. 213-239. [CrossRef]

45. Hodgetts, D.; Gawthorpe, R.L.; Wilson, P.; Rarity, F. Integrating digital and traditional field techniques using virtual reality geological studio (VRGS). In Proceedings of the Society of Petroleum Engineers 69th European Association of Geoscientists and Engineers Conference and Exhibition 2007, London, UK, 11-14 June 2007; pp. 83-87. [CrossRef]

46. Zingg, T. Beitrag zur Schotteranalyse. Schweizerische Mineralogische und Petrographische Mitteilungen 1935, 15, 39-140. 
47. Lynch, L.F. Frio shale mineralogy and the stoichiometry of the smectite to illite reaction-The most important reaction in sedimentary diagenesis. Clays Clay Miner. 1997, 45, 618-631. [CrossRef]

48. Mutti, E. Turbidite Sandstones; AGIP, Istituto di Geologia, Università di Parma: Parma, Italy, 1992.

49. Bouma, A.H. Sedimentology of Some Flysch Deposits: A graphic Approach to Facies Interpretation; Elsevier: Amsterdam, The Netherlands, 1962; Volume 168.

50. Barton, M.; O’Byrne, C.; Pirmez, C.; Prather, B.; Van der Vlugt, F.; Alpak, F.O.; Sylvester, Z. Turbidite channel architecture: Recognizing and quantifying the distribution of channel base drapes using core and dipmeter data. In Dipmeter and Borehole Image Log Technology; Pöppelreiter, M., Garcia-Carballido, C., Kraaijveld, M.A., Eds.; AAPG Memoir: Houston, TX, USA, 2010; Volume 92, pp. 195-210. [CrossRef]

51. McHargue, T.; Pyrcz, M.J.; Sullivan, M.D.; Clark, J.D.; Fildani, A.; Romans, B.W.; Covault, J.A.; Levy, M.; Posamentier, H.W.; Drinkwater, N.J. Architecture of turbidite channel systems on the continental slope: Patterns and predictions. Mar. Pet. Geol. 2011, 28, 728-743. [CrossRef]

52. Janocko, M.; Nemec, W.; Henriksen, S.; Warchoł, M. The diversity of deep-water sinuous channel belts and slope valley-fill complexes. Mar. Pet. Geol. 2013, 41,7-34. [CrossRef]

53. Ebdon, D. Statistics in Geography: A Practical Approach-Revised with 17 Programs; Blackwell: Oxford, UK, 1985.

54. Folk, R.L. Petrology of Sedimentary Rocks; Hemphill Publishing Company: Austin, TX, USA, 1980.

55. Worden, R.H.; Morad, S. Clay minerals in sandstones: Controls on formation, distribution and evolution. In Clay Mineral Cements in Sandstones; Worden, R.H., Morad, S., Eds.; International Association of Sedimentologists Special Publication: Oxford, UK, 2003; Volume 34, pp. 3-41. [CrossRef]

56. Machel, H.-G. Cathodoluminescence in calcite and dolomite and its chemical interpretation. Geosci. Can. 1983, 12, 139-147.

57. Tucker, M.; Wright, V.P. Carbonate Sedimentology; Blackwell Science: Oxford, UK, 1990; 482p. [CrossRef]

58. Flügel, E. Microfacies of Carbonate Rocks; Springer: Berlin/Heidelberg, Germany, 2004; 976p. [CrossRef]

59. Hiatt, E.E.; Pufahl, P.K. Cathodoluminescence petrography of carbonate rocks: Application to understanding diagenesis, reservoir quality, and pore system evolution. In Cathodoluminescence and Its Application to Geoscience; Coulson, I., Ed.; Short Course Series; Mineralogical Association of Canada: Quebec, QC, Canada, 2014; Volume 45, pp. 75-96.

60. Zachos, J.; Pagani, M.; Sloan, L.; Thomas, E.; Billups, K. Trends, rhythms, and aberrations in global climate 65 Ma to present. Science 2001, 292, 686-693. [CrossRef]

61. Swart, P.K. The geochemistry of carbonate diagenesis: The past, present and future. Sedimentology 2015, 62, 1233-1304. [CrossRef]

62. Dale, A.; John, C.M.; Mozley, P.S.; Smalley, P.C.; Muggeridge, A.H. Time-capsule concretions: Unlocking burial diagenetic processes in the Mancos Shale using carbonate clumped isotopes. Earth Planet. Sci. Lett. 2014, 394, 30-37. [CrossRef]

63. Klein, J.S.; Mozley, P.; Campbell, A.R.; Cole, R. Spatial distribution of carbon and oxygen isotopes in laterally extensive carbonate-cemented layers; implications for mode of growth and subsurface identification. J. Sediment. Res. 1999, 69, 184-201. [CrossRef]

64. Eschard, R.; Deschamps, R.; Doligez, B.; Lerat, O.; Langlais, V.; Euzen, T. Connectivity estimation between turbiditic channels and overbank deposits from the modelling of an outcrop analogue (Pab Formation, Maastrichtian, Pakistan). Geol. Soc. Lond. Spec. Publ. 2014, 387, 203-231. [CrossRef]

65. Gardner, M.H.; Borer, J.M.; Bouma, A.H.; Stone, C.G. Submarine channel architecture along a slope to basin profile, Brushy Canyon Formation, west Texas; Special Publication-SEPM: Houston, TX, USA, 2000; Volume 68, pp. 195-214.

66. Cunha, L.B.; Barroso, A.D.S.; Romeu, R.K.; Sombra, C.L.; Cortez, M.M.; Backheuser, Y.; Lopes, M.F.; Schwerdesky, G.; Bruhn, C.H.; de Souza, R.S.; et al. A multi-scale approach to improve reservoir characterization and forecasting: The Albacora Field (deep-water offshore Brazil) study. Pet. Geosci. 2001, 7, S17-S23. [CrossRef]

(C) 2019 by the authors. Licensee MDPI, Basel, Switzerland. This article is an open access article distributed under the terms and conditions of the Creative Commons Attribution (CC BY) license (http://creativecommons.org/licenses/by/4.0/). 